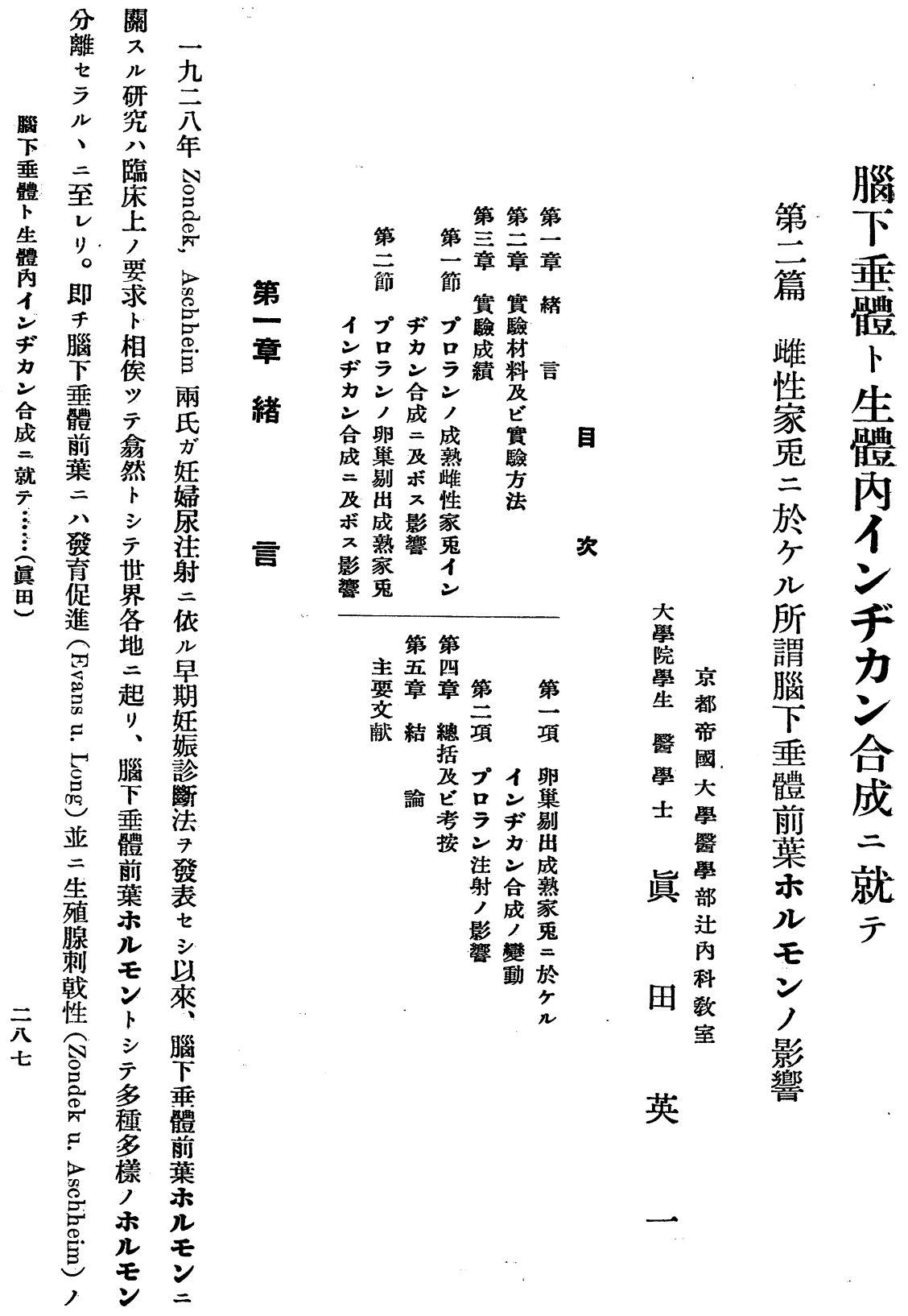


垂 體 ヂ 暴 就 所

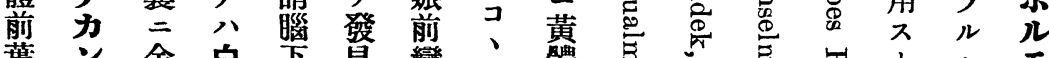

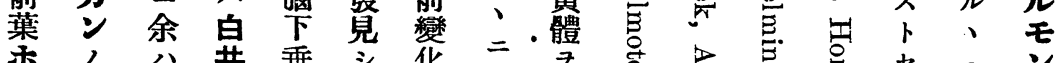

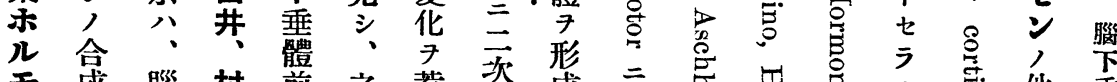

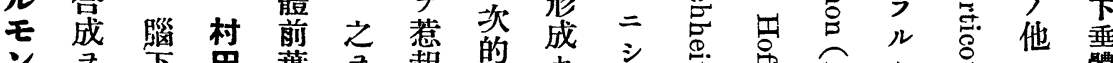
フ

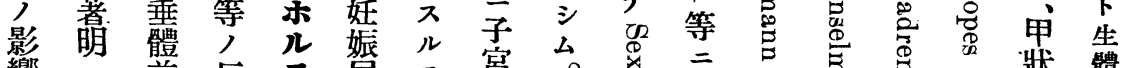

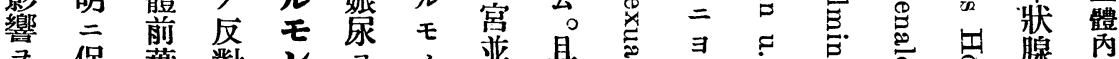
7 促葉 對ン $ン$ 亚县坣

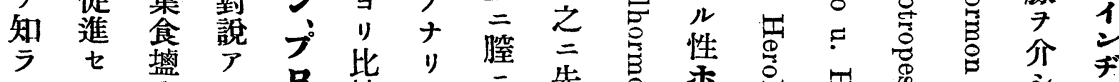

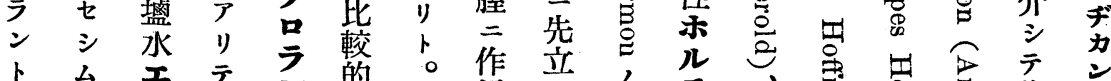

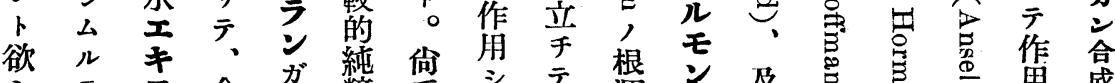

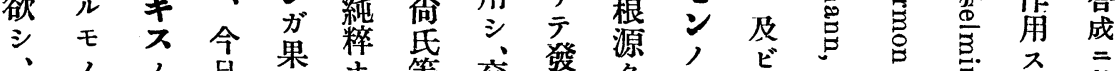

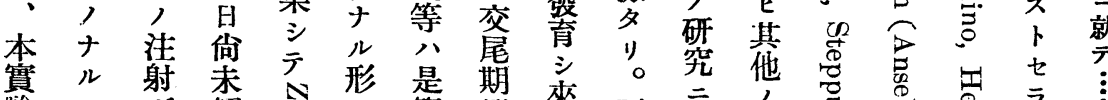

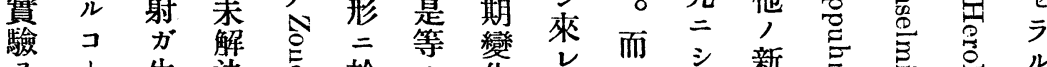

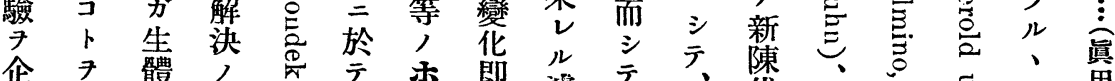

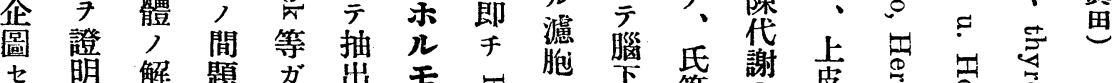
七明解 題 ガ 出 モ

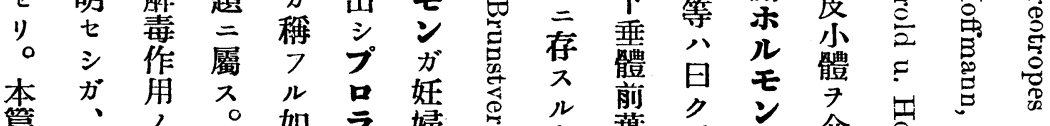
二更一、如

於 二

テ 弤 モ

八娠 見 先㽷 做 当雌当只

性排 キ

家冤七 泄

二ラ

及ル

ホ、、ル

影 今 注 ク、卡尿艿巢

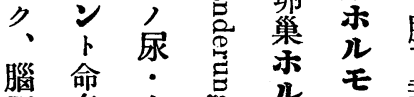

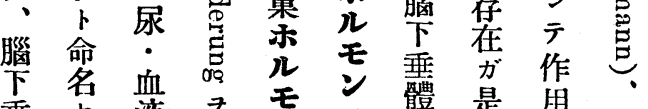
$\stackrel{\vdots}{\vdots}$

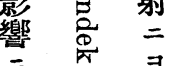

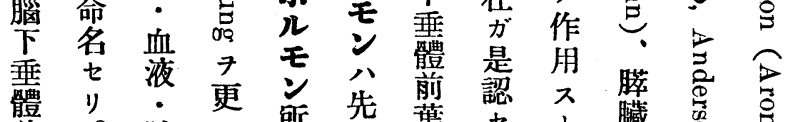

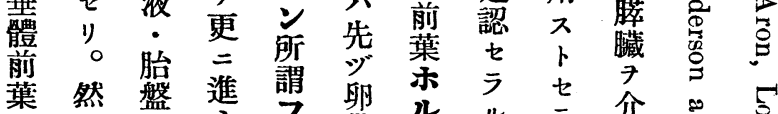
小 $v$ 篮

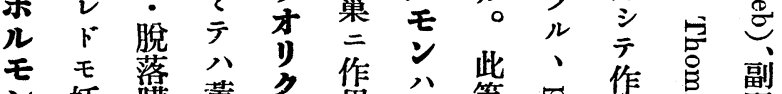

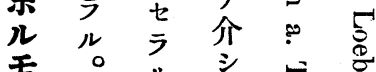

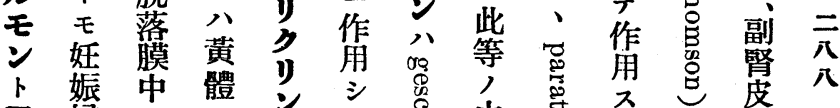
就ノル 述譄 軆 同妢 = J 一务多作心之副

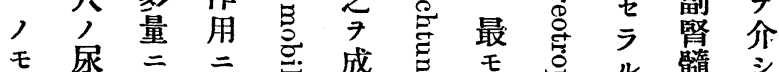
モ 尿示 ジ腦 内 
膟

重

点

生

內

队

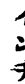

年

カ

合 か ぷ 實

虔

就

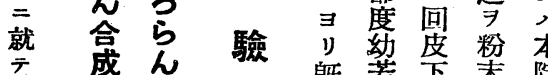

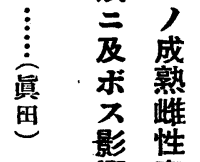

家

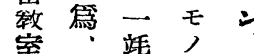

至調 $\Rightarrow$ フ

成再方注

5)

績

ラル 但 芰

レ 效 シ 。 ビ

夕妿此而入

ル 試 驗 濃 テ 患
五，溶

留作、涯謂り

剔用家三腦。ド前ン定每動

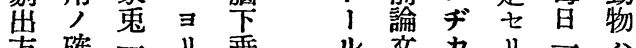

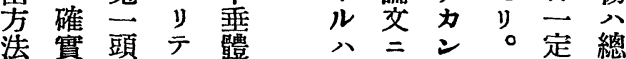

$=\exists=$ 調 前

就期就製 葉

茀 、ンソタ ル

第第當ガノルモ

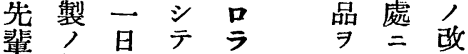

三都 $\frac{1}{2}$ 用分良

七 省 シ

之略 タ

既若下禾院

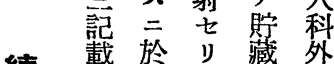

爫行蔗使者

省 行於時

略 テケ 妊

不檢 該每娠

せ ホ 回診

尿實

量 量 于

$=$

動十者

物分光

吡, 尿

位相 寻

之嘗

決定隇

菜

シ溜 ル 
第一表，成熟䧳性家鬼プロラン連續注射（第一例）

\begin{tabular}{|c|c|c|c|c|c|c|c|c|}
\hline 月日 & 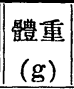 & $\begin{array}{c}\text { 尿量 } \\
(\mathrm{ccm})\end{array}$ & 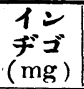 & $\begin{array}{l}\text { 1ンデ } \\
\text { カ } \\
(\mathrm{mg})\end{array}$ & $\begin{array}{l}\text { 合成イン } \\
F \text { カ } \\
(\mathrm{mg})\end{array}$ & $\begin{array}{c}\text { 換算イン } \\
\text { F } \\
(\mathrm{mg})\end{array}$ & \begin{tabular}{|c|} 
合成率 \\
$(\%)$
\end{tabular} & 摘 \\
\hline $4 / \mathrm{VI}$ & 1920 & 220 & 0.154 & 0.295 & \multirow{8}{*}{6.501} & \multirow{8}{*}{3.030} & \multirow{8}{*}{18.94} & \multirow{8}{*}{ インドール16ing注射 } \\
\hline $5 / 11$ & 1900 & 224 & 0.202 & 0.387 & & & & \\
\hline $6 / 1 /$ & 1905 & 212 & 0.244 & 0.468 & & & & \\
\hline $7 / 11$ & 1910 & 168 & 0.343 & 0.658 & & & & \\
\hline 平均 & & & 0.236 & 0.452 & & & & \\
\hline $8 / \mathrm{VII}$ & 1925 & 206 & 3.627 & 6.953 & & & & \\
\hline $9 / 1 /$ & 1915 & 194 & 0.213 & 0.408 & & & & \\
\hline $10 / \|$ & 1930 & 182 & 0.200 & 0.383 & & & & \\
\hline $11 / \mathrm{VII}$ & 1925 & 160 & 0.376 & 0.721 & \multirow{7}{*}{7.540} & \multirow{7}{*}{3.514} & \multirow{7}{*}{21.96} & \multirow{5}{*}{$\begin{array}{c}\text { プロラン } 1 \text { c.c. 注射 } \\
\text { " } \\
\text { " } \\
\text { " }\end{array}$} \\
\hline $12 / / 1$ & 1960 & 206 & 0.365 & 0.700 & & & & \\
\hline $13 / / /$ & 1935 & 225 & 0.233 & 0.447 & & & & \\
\hline $14 / " \prime$ & 1950 & 184 & 0.125 & 0.240 & & & & \\
\hline 本均 & & & 0.275 & 0.527 & & & & \\
\hline $15 / \mathrm{VI}$ & 2000 & 202 & 4.208 & 8.067 & & & & \multirow{2}{*}{$\begin{array}{l}\left\{\begin{array}{l}\text { イ゚レトール16mg 及ビ } \\
\text { プロラン } 1 \text { c.c. 注射 }\end{array}\right. \\
\text { プロラン } 1 \text { c.c. 注射 }\end{array}$} \\
\hline $16 / \prime \prime$ & 2020 & 172 & 0.168 & 0.322 & & & & \\
\hline $17 / \mathrm{VI}$ & 2005 & 198 & 0.304 & 0.583 & \multirow{7}{*}{5.567} & \multirow{7}{*}{2.594} & \multirow{7}{*}{16.21} & \multirow{4}{*}{$\begin{array}{c}\text { プロラン } 1 \text { c.c. 注射 } \\
\text { " } \\
\text { " }\end{array}$} \\
\hline $18 / 1 /$ & 2015 & 168 & 0.161 & 0.309 & & & & \\
\hline $19 / 1 /$ & 2030 & 190 & 0.281 & 0.539 & & & & \\
\hline 平均 & & & 0.249 & 0.477 & & & & \\
\hline $20 / \mathrm{VII}$ & 2050 & 180 & 3.153 & 6.044 & & & & $\left\{\begin{array}{l}\text { イ゚ンドール16mg及ビ } \\
\text { プロラン } 1 \text { c.c. 注射 }\end{array}\right.$ \\
\hline $21 / 1$ & 2025 & 196 & 0.346 & 0.663 & & & & \\
\hline $22 / "$ & 2030 & 182 & 0.490 & 0.939 & & & & \\
\hline
\end{tabular}
畓当求 得。

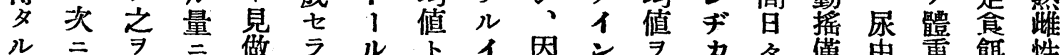

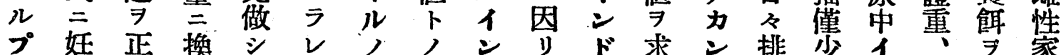

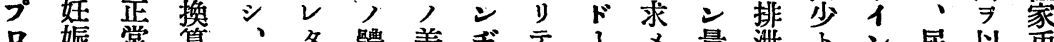

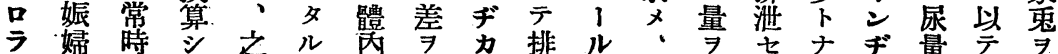
人

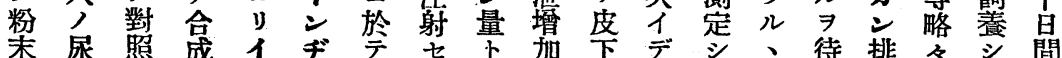

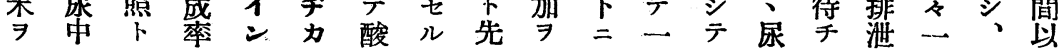


苐二表 成熟䧳性家鬼プロラン連續注射（第二例）

\begin{tabular}{|c|c|c|c|c|c|c|c|c|}
\hline 月日 & 體重 & $\begin{array}{r}\begin{array}{r}\text { 尿量 } \\
(\mathrm{ccm})\end{array} \\
\end{array}$ & $\begin{array}{l}\text { イシ } \\
\text { F゙ご } \\
(\mathrm{mg})\end{array}$ & 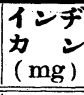 & 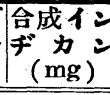 & 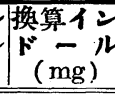 & \begin{tabular}{|c|}
$\mid \begin{array}{c}\text { 合成率 } \\
(\%)\end{array}$ \\
\end{tabular} & 要 \\
\hline $4 / \mathrm{VII}$ & 2185 & 218 & 0.336 & 0.644 & \multirow{8}{*}{6.965} & \multirow{8}{*}{3.246} & \multirow{8}{*}{20.29} & \multirow{8}{*}{ インドール16mg注射 } \\
\hline $5 / 11$ & 2180 & 200 & 0.416 & 0.797 & & & & \\
\hline $6 / / /$ & 2170 & 222 & 0.483 & 0.926 & & & & \\
\hline $7 / / /$ & 2180 & 198 & 0.589 & 1.129 & & & & \\
\hline 平均 & & & 0.456 & 0.874 & & & & \\
\hline $8 / \mathrm{VII}$ & $\| 2195$ & 184 & 4.089 & 7.839 & & & & \\
\hline $9 / / /$ & 2200 & 168 & 0.441 & 0.845 & & & & \\
\hline $10 / / /$ & 2190 & 190 & 0.127 & 0.243 & & & & \\
\hline $11 / \mathrm{VII}$ & 2205 & 192 & 0.360 & 0.690 & \multirow{7}{*}{7.678} & \multirow{7}{*}{3.578} & \multirow{7}{*}{22.36} & \multirow{7}{*}{ 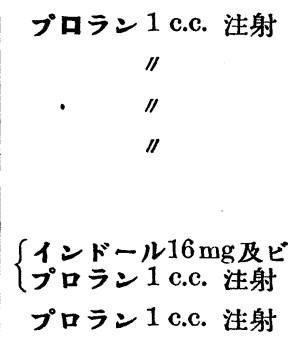 } \\
\hline $12 / / 1$ & 2210 & 178 & 0.405 & 0.776 & & & & \\
\hline $13 / \|$ & 2215 & 182 & 0.306 & 0.587 & & & & \\
\hline $14 / /$ & 2220 & 184 & 0.461 & 0.884 & & & & \\
\hline 平均 & & & 0.383 & 0.734 & & & & \\
\hline $15 / \mathrm{VII}$ & 2210 & 194 & 4.388 & 8.412 & & & & \\
\hline $16 / \|$ & 2215 & 198 & 0.346 & 0.663 & & & & \\
\hline $17 / \mathrm{VII}$ & 2240 & 204 & 0.122 & 0.234 & \multirow{7}{*}{5.872} & \multirow{7}{*}{2.796} & \multirow{7}{*}{17.10} & \multirow{4}{*}{$\begin{array}{c}\text { プロラン } 1 \text { c.c. 注射 } \\
\text { " } \\
\text { " }\end{array}$} \\
\hline $18 / / /$ & 2200 & 234 & 痕跡 & 痕跡 & & & & \\
\hline $19 / /$ & 2210 & 176 & 0.114 & $0.2 \mathrm{I} 9$ & & & & \\
\hline 平均 & & & 0.079 & 0.151 & & & & \\
\hline $20 /$ VII & 2205 & 198 & 3.142 & 6.023 & & & & 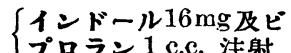 \\
\hline $21 / "$ & 2190 & 184 & 0.301 & 0.577 & & & & \\
\hline $22 / 1 /$ & 2195 & 208 & 0.208 & | 0.399 & & & & \\
\hline
\end{tabular}

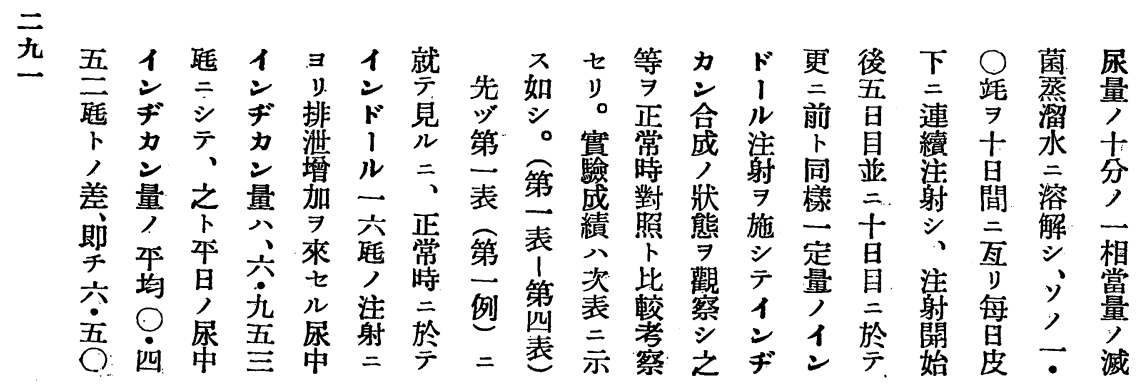


第三表 成熟雌性家鬼プロラン連續注射（第三例）

\begin{tabular}{|c|c|c|c|c|c|c|c|c|}
\hline 月日 & 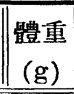 & $\begin{array}{c}\begin{array}{c}\text { 尿量 } \\
(\mathrm{ccm})\end{array} \\
\end{array}$ & $\begin{array}{l}\text { イン } \\
\text { ヂゴ } \\
(\mathrm{mg})\end{array}$ & $\begin{array}{l}\text { 1ンチ } \\
\text { カ } 2 \\
(\mathrm{mg})\end{array}$ & 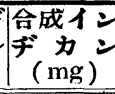 & $\begin{array}{l}\text { 換算イン } \\
\text { Fー ル } \\
\text { (img) }\end{array}$ & \begin{tabular}{|c|} 
合成率 \\
$(\%)$
\end{tabular} \mid & 摘 \\
\hline $4 / \mathrm{VII}$ & 2110 & 182 & 0.310 & 0.594 & \multirow{8}{*}{6.358} & \multirow{8}{*}{2.963} & \multirow{8}{*}{18.52} & \multirow{8}{*}{ インドール16mg注射 } \\
\hline $5 / 1 /$ & 2135 & 196 & 0.201 & 0.385 & & & & \\
\hline $6 / / 1$ & 2140 & 212 & 0.233 & 0.447 & & & & \\
\hline $7 / 1 /$ & 2130 & 178 & 0.274 & 0.525 & & & & \\
\hline 本均 & & & 0.255 & 0.488 & & & & \\
\hline $8 / \mathrm{VI}$ & 2110 & 250 & 3.571 & 6.846 & & & & \\
\hline $9 / 1 /$ & 2115 & 164 & 0.344 & 0.659 & & & & \\
\hline $10 / / /$ & $\mid 2110$ & 182 & 0.254 & 0.487 & & & & \\
\hline $11 / \mathrm{VI}$ & 2100 & 168 & 0.157 & 0.301 & \multirow{7}{*}{7.812} & \multirow{7}{*}{3.640} & \multirow{7}{*}{22.75} & \multirow{7}{*}{ 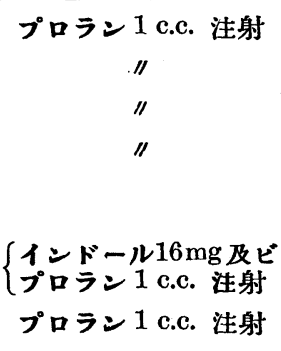 } \\
\hline $12 / \|$ & 2125 & 202 & 0.315 & 0.604 & & & & \\
\hline $13 / / \prime$ & 2145 & 182 & $\cdot 0.129$ & 0.247 & & & & \\
\hline $14 / / 1$ & 2140 & 180 & 0.351 & 0.673 & & & & \\
\hline 本均 & & & 0.238 & 0.456 & & & & \\
\hline $15 / \mathrm{VII}$ & 2135 & 246 & 4.313 & 8.268 & & & & \\
\hline $16 / / 1$ & $\mid 2170$ & 210 & 0.259 & 0.497 & & & & \\
\hline $17 / \mathrm{VI}$ & $\mid 2150$ & 182 & 0.337 & 0.646 & \multirow{7}{*}{5.912} & \multirow{7}{*}{2.755} & \multirow{7}{*}{17.22} & \multirow{7}{*}{ 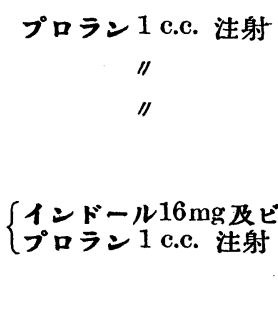 } \\
\hline $18 / \|$ & 2155 & 186 & 0.489 & 0.937 & & & & \\
\hline $19 / " \prime$ & 2120 & 216 & 0.212 & 0.406 & & & & \\
\hline 平均 & & & 0.346 & 0.663 & & & & \\
\hline $20 /$ VI & 2125 & 210 & $3.4: 0$ & 6.575 & & & & \\
\hline $21 / "$ & 2110 & 176 & 0.156 & 0.299 & & & & \\
\hline $22 / 1 /$ & 2130 & 198 & 0.238 & 0.456 & & & & \\
\hline
\end{tabular}

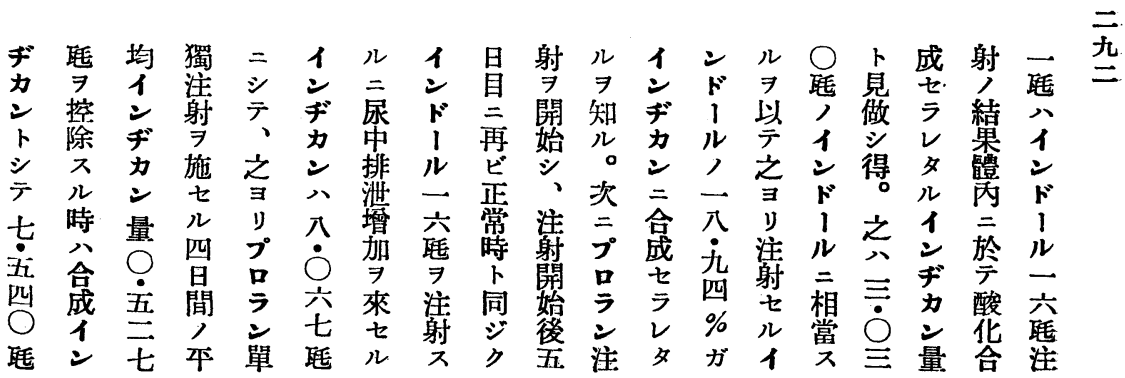


茅四衰 成熟雌性家鬼プロラン連續注射（第四例）

\begin{tabular}{|c|c|c|c|c|c|c|c|c|}
\hline 月日 & \begin{tabular}{||c} 
體重 \\
$(\mathrm{g})$
\end{tabular} & $\begin{array}{r}\begin{array}{r}\text { 尿量 } \\
(\mathrm{ccm})\end{array} \\
\end{array}$ & $\begin{array}{l}\text { イン } \\
\text { ギゴ } \\
(\mathrm{mg})\end{array}$ & $\begin{array}{l}\text { インヂ } \\
\text { カ2 } \\
(\mathrm{mg})\end{array}$ & \begin{tabular}{|} 
合成1ン \\
$\begin{array}{c}\text { カ } \\
(\mathrm{mg})\end{array}$
\end{tabular} & $\begin{array}{c}\text { 換算イン } \\
(\overline{\mathrm{mg}}) \\
\end{array}$ & $\mid$\begin{tabular}{|c|}
$\left|\begin{array}{c}\text { 合成率 } \\
(\%)\end{array}\right|$ \\
\end{tabular} & 摘 \\
\hline $4 / \mathrm{VII}$ & 2050 & 170 & 0.419 & 0.803 & \multirow{8}{*}{6.608} & \multirow{8}{*}{3.079} & \multirow{8}{*}{19.24} & \multirow{8}{*}{ インドールI6mg注射 } \\
\hline $5 / 1 /$ & 2065 & 192 & 0.288 & 0.552 & & & & \\
\hline $6 / 1 /$ & 2050 & 256 & 0.215 & 0.412 & & & & \\
\hline $7 / 1 /$ & 2060 & 186 & 0.374 & 0.717 & & & & \\
\hline 平均 & & & 0.324 & 0.621 & & & & \\
\hline 8 I VII & 2050 & 198 & 3.771 & 7.229 & & & & \\
\hline $9 / 1 "$ & 2065 & 170 & 0.245 & 0.470 & & & & \\
\hline $10 / \prime \prime$ & 2075 & 184 & 0.199 & 0.381 & & & & \\
\hline $11 / \mathrm{XI}$ & 2100 & 188 & 0.135 & 0.259 & \multirow{7}{*}{7.226} & \multirow{7}{*}{$\mathbf{3 . 3 6 7}$} & \multirow{7}{*}{21.04} & \multirow{7}{*}{ 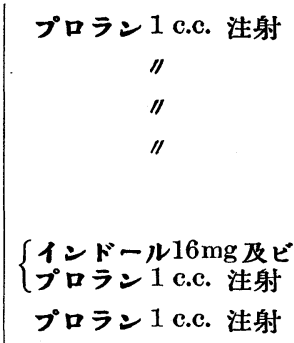 } \\
\hline $12 / \|$ & 2090 & 192 & 0.163 & 0.312 & & & & \\
\hline $13 / / /$ & 2105 & 224 & 0.202 & 0.387 & & & & \\
\hline $14 \prime^{\prime \prime \prime}$ & 2145 & 204 & 0.269 & 0.516 & & & & \\
\hline 平均 & & & 0.192 & 0.369 & & & & \\
\hline $15 / \mathrm{VII}$ & 2195 & 208 & 3.962 & 7.595 & & & & \\
\hline $16 / 1 /$ & 2145 & 180 & 0.225 & 0.431 & & & & \\
\hline $17 / \mathrm{VI}$ & $\mid 2125$ & 166 & 0.248 & 0.475 & \multirow{7}{*}{5.643} & \multirow{7}{*}{2.630} & \multirow{7}{*}{16.44} & \multirow{4}{*}{$\begin{array}{c}\text { プロラン } 1 \text { c.c. 注射 } \\
\text { " } \\
\text { " }\end{array}$} \\
\hline $18 / / \prime$ & 2130 & 182 & 0.205 & 0.393 & & & & \\
\hline $19 / / 1$ & 2180 & 182 & 0.316 & 0.606 & & & & \\
\hline 平均 & & & 0.256 & 0.491 & & & & \\
\hline $20 / \mathrm{VI}$ & 2200 & 210 & 3.200 & 6.134 & & & & 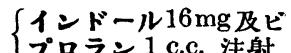 \\
\hline $21 / / /$ & 2170 & 162 & 0.230 & 0.441 & & & & \\
\hline $22 / / 1$ & 2155 & 184 & 0.175 & 0.335 & & & & \\
\hline
\end{tabular}

草

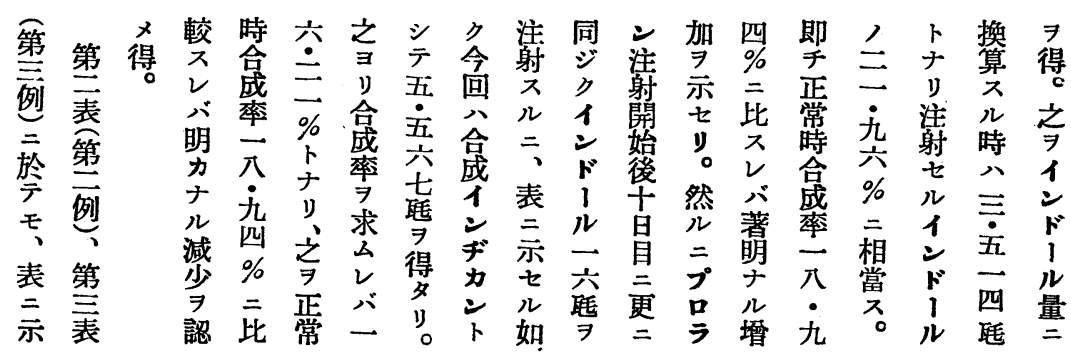




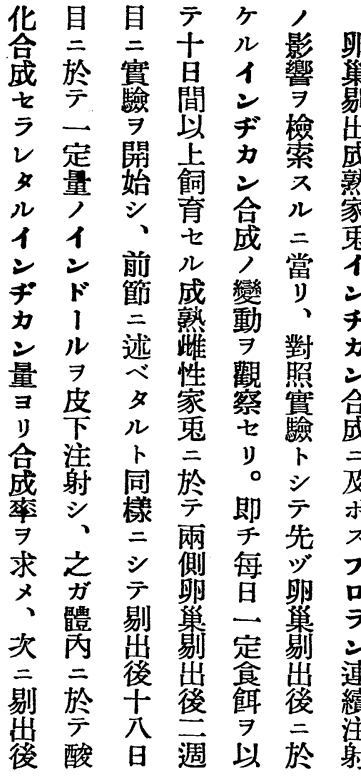

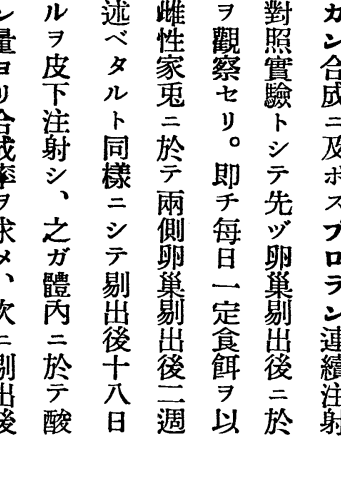

量

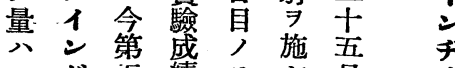

七ド吾績モ染旦

呬儿表公人

吾立第表比爫 ビ 喊

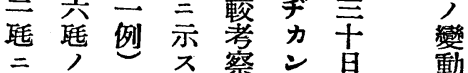

シ 注 $\Rightarrow$ 如察合目動

テ射見梁り膥

、

之 $\exists$ 第 牀 前

㴬渄雨吾 表

前增留第察樣

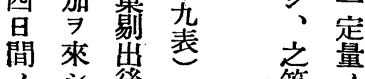

, 等集

本

11 日 出

$\div \div$ 目

ギギ

後仙

第
ル゙例シ墰 1 七

$=$ 力占区 加光ル

口八傾 $テ$ 示力

ラ六向減セ全

吾六三少

日公云企樣垂

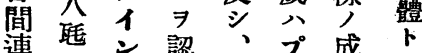

連 䈍

集テ! 方日

第分威

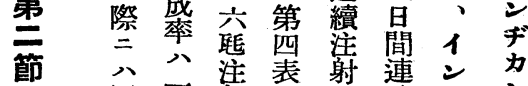

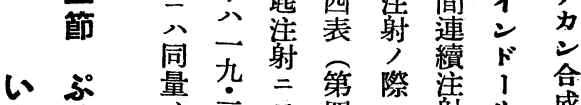

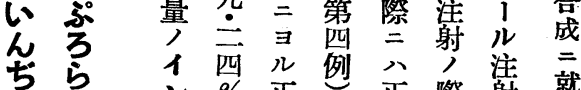
加 $几$ i $\%$ 正政 際射 就

人)

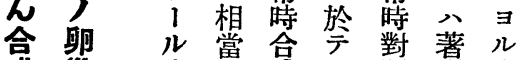

成巢注畋成照奛生产

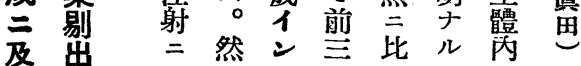

热成

ス 熟

影富

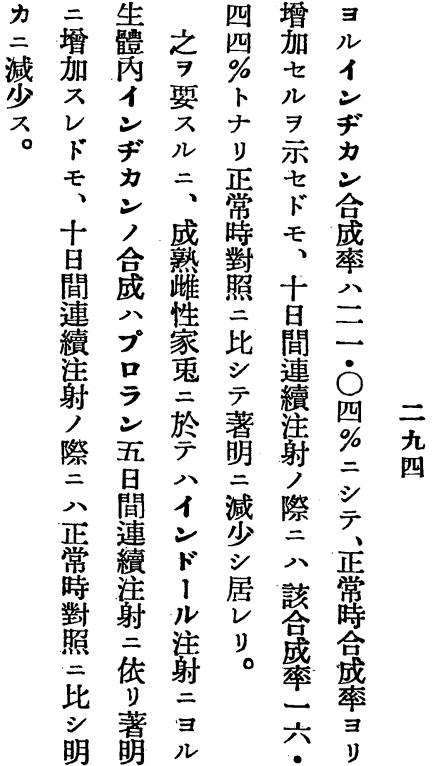


苐五表、卵巢剔出成熟家鬼對照試驗（第一例）

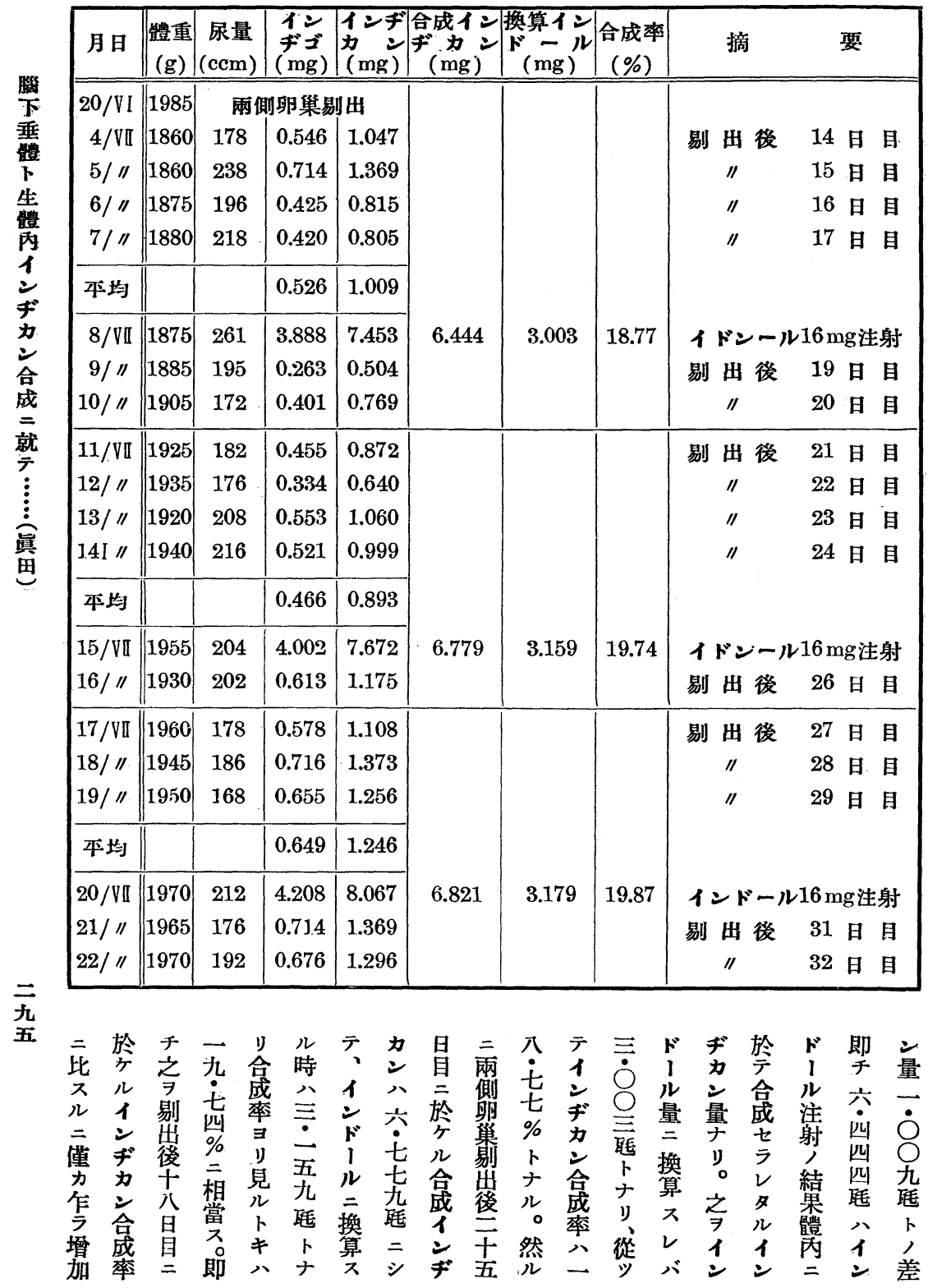


第六表 卵菓剔出成熟家鬼對照試驗（第二側）

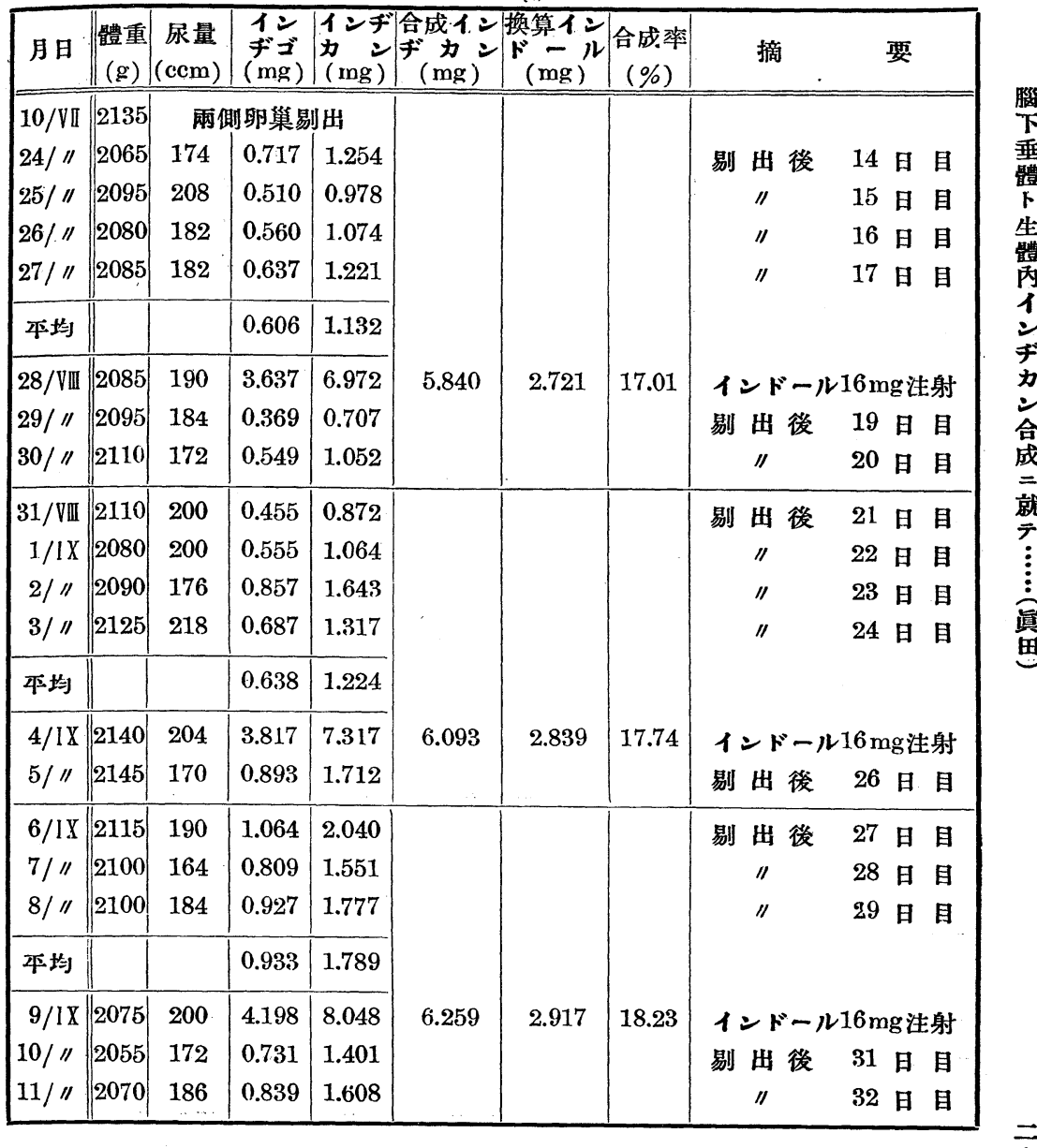

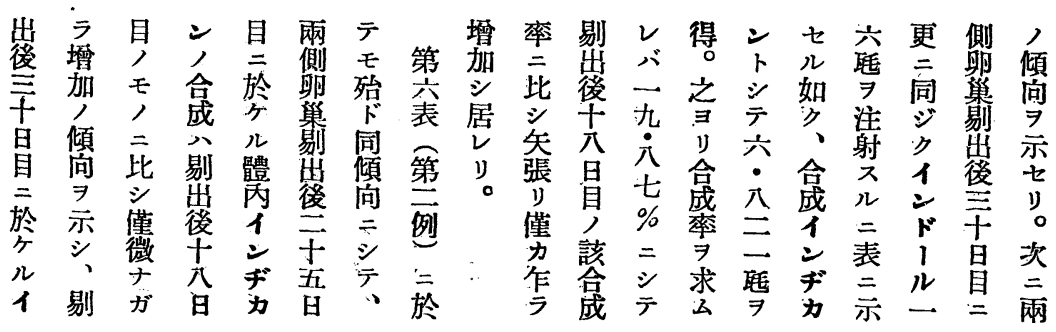


第七表 卵巢剔出成熟家鬼對照試第三例）

\begin{tabular}{|c|c|c|c|c|c|c|c|c|c|}
\hline 月日 & 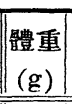 & $\begin{array}{l}\text { 尿量 } \\
\text { (ccm) }\end{array}$ & $\mid \begin{array}{c}1 \pm \\
\text { f゙ت゙ } \\
(\mathrm{mg})\end{array}$ & 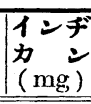 & 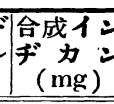 & 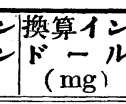 & 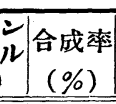 & 摘 & 要 \\
\hline $10 / \mathrm{VII}$ & 1955 & & 㑡卵柋易! & & \multirow{9}{*}{6.101} & \multirow{9}{*}{2.843} & \multirow{9}{*}{17.77} & \multirow{6}{*}{$\begin{array}{c}\text { 剔 出 後 } \\
\text { " } \\
" 1 \\
" 1\end{array}$} & \multirow{6}{*}{$\begin{array}{l}14 \text { 日 } \\
15 \text { 日 } \\
16 \text { 日 } \\
17 \text { 日 } \\
17 \text { 日 }\end{array}$} \\
\hline $24 / " 1$ & 1810 & 172 & 0.585 & 1.121 & & & & & \\
\hline $25 / 11$ & 1805 & 196 & 0.343 & 0.658 & & & & & \\
\hline $26 / " 1$ & 1815 & 182 & 0.657 & 1.259 & & & & & \\
\hline $27 / 11$ & 1825 & 178 & 0.581 & 1.114 & & & & & \\
\hline 平均 & & & 0.542 & 1.038 & & & & & \\
\hline $28 /$ VII & $\mid 1810$ & 216 & 3.724 & 7.139 & & & & \multicolumn{2}{|c|}{ インドール16 mg注射 } \\
\hline $29 / 1 /$ & 1845 & 170 & 0.386 & 0.740 & & & & 剔出 後 & 19 日目 \\
\hline $30 / / 1$ & 1805 & 184 & 0.359 & 0.688 & & & & "I & 20 日目 \\
\hline $31 / \mathrm{VII}$ & $\mid 1820$ & 198 & 0.693 & 1.328 & \multirow{7}{*}{6.247} & \multirow{7}{*}{2.911} & \multirow{7}{*}{18.19} & \multirow{5}{*}{\multicolumn{2}{|c|}{$\begin{array}{ccc}\text { 剔 出後 } & 21 \text { 日 } \text { 目 } \\
\text { " } & 22 \text { 日 } \\
\text { " } & 23 \text { 日 } \\
\text { " } & 24 \text { 日 } \\
\text { " } & \end{array}$}} \\
\hline $1 / I X$ & $\mid 1850$ & 180 & 0.260 & 0.498 & & & & & \\
\hline $2 / 11$ & $\mid 1865$ & 220 & 0.295 & 0.566 & & & & & \\
\hline $3 / 11$ & $|1875|$ & 174 & 0.365 & 0.700 & & & & & \\
\hline 本均 & & & 0.403 & 0.773 & & & & & \\
\hline $4 / 1 X$ & $\mid 1880$ & 212 & 3.662 & 7.020 & & & & \multicolumn{2}{|c|}{ インドール16 mg注射 } \\
\hline $5 / 11$ & $\mid 1890$ & 190 & 0.131 & 0.251 & & & & 剔 出 後 & 26 日目 \\
\hline $6 / I X$ & $\mid 1895$ & 184 & 0.547 & 1.049 & \multirow{7}{*}{5.911} & \multirow{7}{*}{2.755} & \multirow{7}{*}{17.22} & \multirow{3}{*}{\multicolumn{2}{|c|}{$\begin{array}{cccc}\text { 剔 出後 } & 27 & \text { 日 } & \text { 目 } \\
\prime \prime & 28 & \text { 日 } & \text { 目 } \\
\text { " } & 29 & \text { 日 }\end{array}$}} \\
\hline $7 / 1 /$ & $|1890|$ & 172 & 0.472 & 0.905 & & & & & \\
\hline $8 / 11$ & $\mid 1900$ & 164 & 0.627 & 1.202 & & & & & \\
\hline 本均 & & & 0.549 & 1.052 & & & & \multirow{2}{*}{\multicolumn{2}{|c|}{ インドール16 mg注射 }} \\
\hline $9 / 1 \mathrm{X}$ & $\mid 1885$ & 196 & 3.632 & 6.963 & & & & & \\
\hline $10 / \|$ & $|1910|$ & 174 & 0.587 & 1.125 & & & & 剔 出 後 & 31 日目 \\
\hline $11 / \|$ & 1900 & 186 & 0.685 & 1.313 & & & & "I & 32 日目 \\
\hline 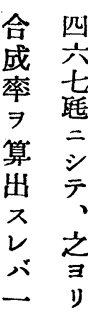 & 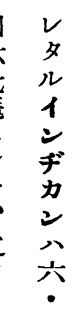 & 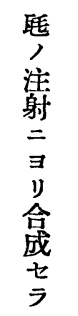 & 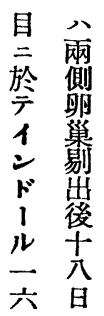 & 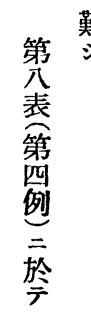 & 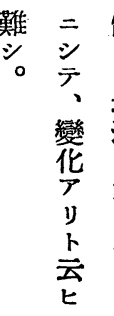 & 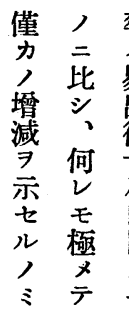 & 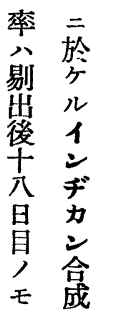 & 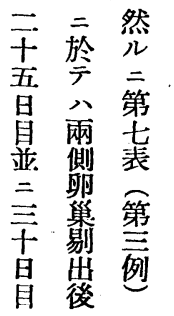 & 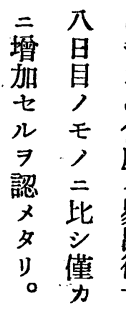 \\
\hline
\end{tabular}


第八表 卵巢剔出成熟家鬼對照試驗（第四例）

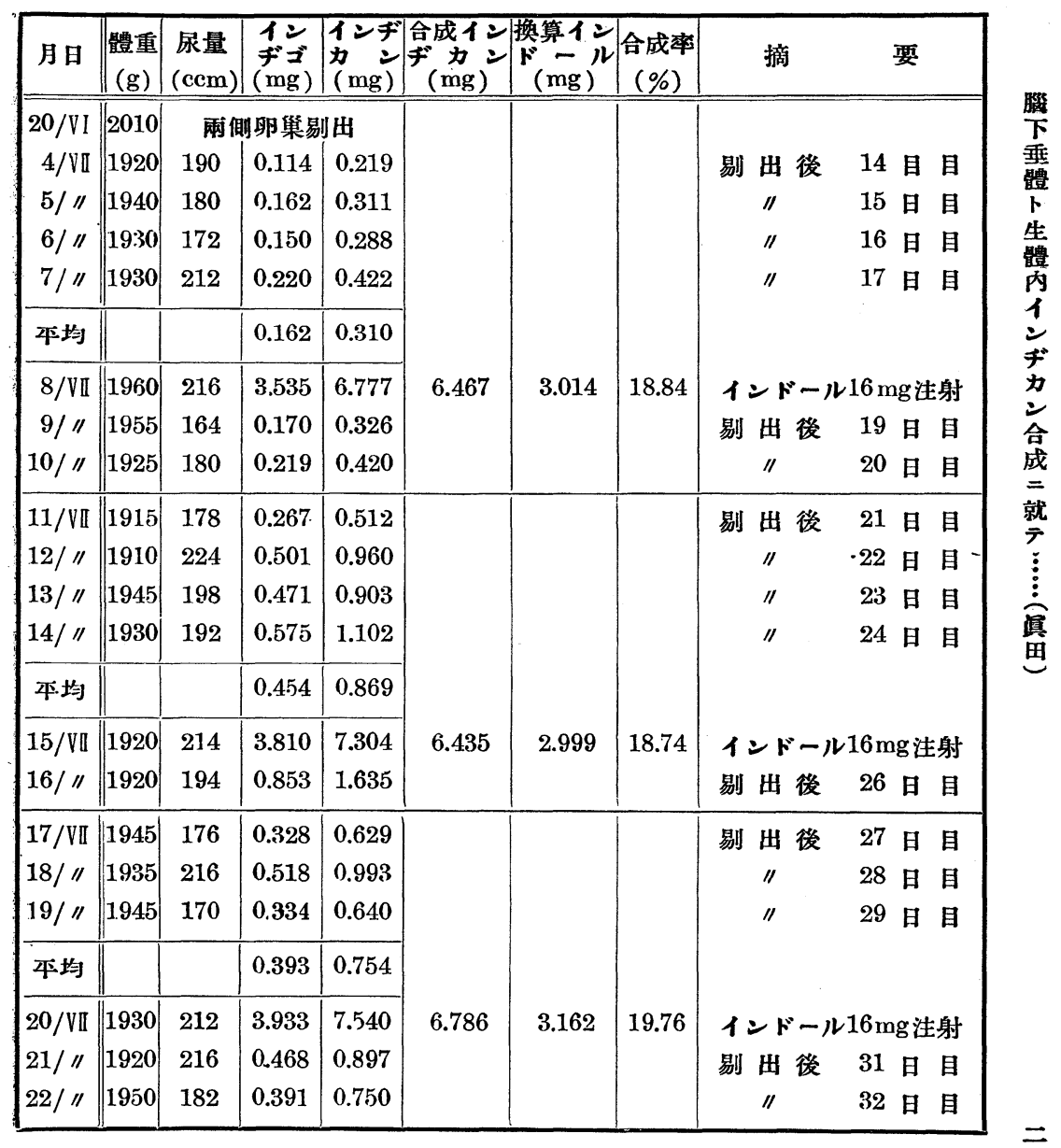

七, 合五 示テ目 \%力十認テ成注於 シ 八

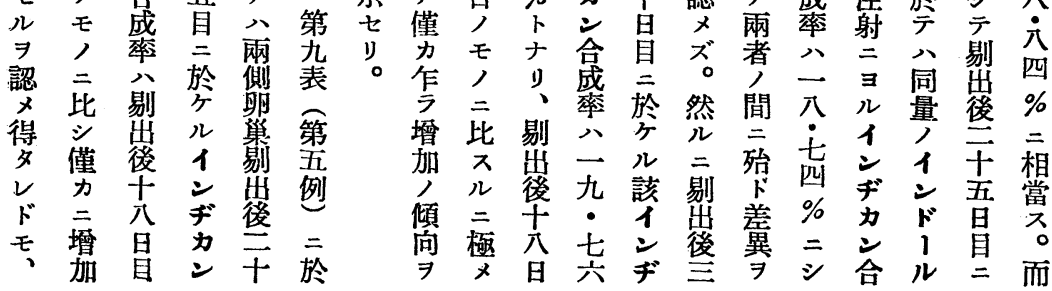


第九表 卵巢剔出成熟家鬼對照試驗（第五例）

\begin{tabular}{|c|c|c|c|c|c|c|c|c|c|}
\hline 月日 & 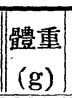 & $\begin{array}{l}\text { 尿量 } \\
(\mathrm{ccm})\end{array}$ & $\begin{array}{l}\text { 1シ } \\
\text { ぞご } \\
\text { ( } \mathrm{mg})\end{array}$ & $\begin{array}{l}\text { 1ンチ } \\
\text { 力 } \\
(\mathrm{mg})\end{array}$ & 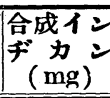 & $\begin{array}{c}\text { 換算イン } \\
(\mathrm{mg})\end{array}$ & $\left\{\begin{array}{l}\text { 合成率 } \\
(\%)\end{array}\right.$ & 摘 & 要 \\
\hline $11 /$ VII & 2220 & & 冽卵巢易 ～～～～ & & \multirow{9}{*}{6.044} & \multirow{9}{*}{2.817} & \multirow{9}{*}{17.61} & \multirow{6}{*}{$\begin{array}{c}\text { 剔 出 後 } \\
" 1 \\
" 1 \\
"\end{array}$} & \multirow[b]{2}{*}{14 日目 } \\
\hline $25 / 11$ & $\mid 2100$ & 180 & 0.393 & 0.753 & & & & & \\
\hline $26 / 1 /$ & 2125 & 194 & 0.471 & 0.903 & & & & & 15 日目 \\
\hline $27 / 11$ & 2100 & 182 & 0.583 & 1.118 & & & & & 16 日目 \\
\hline $28 / 11$ & 2120 & 185 & 0.389 & 0.746 & & & & & 17 日目 \\
\hline 平均 & & & 0.459 & 0.880 & & & & & \\
\hline $29 /$ VII & $\mid 2130$ & 186 & 3.612 & 6.924 & & & & \multicolumn{2}{|c|}{ インドール $16 \mathrm{mg}$ 注射 } \\
\hline $30 / " \prime$ & $\mid 2135$ & 184 & 0.405 & 0.776 & & & & 剔出 後 & 19 日目 \\
\hline $31 / \|$ & $\mid 2140$ & 180 & 0.420 & 0.805 & & & & " & 20 日目 \\
\hline $1 / I X$ & $|2150|$ & 172 & 0.294 & 0.564 & \multirow{7}{*}{6.400} & \multirow{7}{*}{2.982} & \multirow{7}{*}{18.64} & \multirow{5}{*}{\multicolumn{2}{|c|}{ 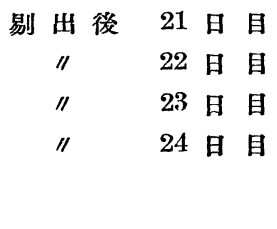 }} \\
\hline $2 / \|$ & $\mid 2120$ & 182 & 0.364 & 0.698 & & & & & \\
\hline $3 / 11$ & $\mid 2135$ & 212 & 0.433 & 0.830 & & & & & \\
\hline $4 / 11$ & 2155 & 184 & 0.558 & 1.070 & & & & & \\
\hline 本均 & & & 0.412 & 0.791 & & & & & \\
\hline $5 / 1 X$ & $|2165|$ & 178 & 3.751 & 7.191 & & & & \multicolumn{2}{|c|}{ インドール $16 \mathrm{mg}$ 洁射 } \\
\hline $6 / 11$ & $\mid 2180$ & 160 & 0585 & 1.121 & & & & 剔 出 後 & 26 日目 \\
\hline $7 / 1 X$ & $|2185|$ & 202 & 0.533 & 1.022 & \multirow{7}{*}{6.138} & \multirow{7}{*}{2.860} & \multirow{7}{*}{17.88} & \multirow{4}{*}{\multicolumn{2}{|c|}{$\begin{array}{ccc}\text { 剔 出後 } & 27 \text { 日 } \mathrm{H} \\
\text { " } & 28 \text { 日目 } \\
\text { " } & 29 \text { 日目 }\end{array}$}} \\
\hline $8 / 11$ & 2180 & 180 & 0.569 & 1.091 & & & & & \\
\hline $9 / 11$ & 2200 & 188 & 0.343 & 0.658 & & & & & \\
\hline 平均 & & & 0.482 & 0.924 & & & & & \\
\hline $10 / I X$ & || $2215 \mid$ & 192 & 3.684 & 7.062 & & & & \multicolumn{2}{|c|}{ インドール16 mg注射 } \\
\hline $11 / " /$ & 2215 & 204 & 0.746 & 1.430 & & & & 剔 出 後 & 31 日目 \\
\hline $12 / \|$ & 2240 & 184 & 0.569 & 1.091 & & & & " & 32 日目 \\
\hline
\end{tabular}

无

九

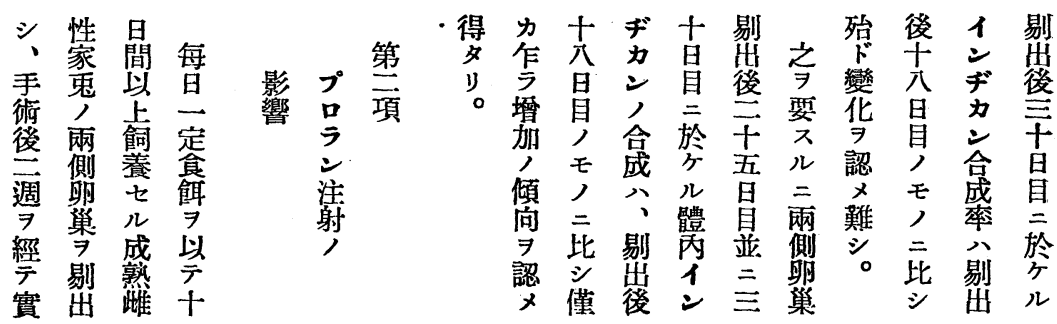


第十表 卵巢剔出成熟家鬼プロラン連續注射（第一例）

\begin{tabular}{|c|c|c|c|c|c|c|c|c|}
\hline 月日 & \begin{tabular}{|l}
$\mid \begin{array}{l}\text { 體重 } \\
(\mathrm{g})\end{array}$ \\
\end{tabular} & $\begin{array}{l}\text { 尿量 } \\
(\mathrm{ccm})\end{array}$ & \begin{tabular}{|l|}
$\begin{array}{l}\text { イ゙ } \\
\text { ヂゴ } \\
(\mathrm{mg})\end{array}$ \\
\end{tabular} & 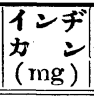 & \begin{tabular}{|l} 
合成イン \\
ギガ \\
$(\mathrm{mg})$
\end{tabular} & $\begin{array}{c}\text { 曆算イン } \\
\text { (mg) }\end{array}$ & \begin{tabular}{|c|}
$\begin{array}{c}\text { 合成率 } \\
(\%)\end{array}$ \\
\end{tabular} & 摘 \\
\hline $11 / \mathrm{VIII}$ & 1945 & \multicolumn{3}{|c|}{ 兩側卵巢剔出 } & \multirow{9}{*}{5.939} & \multirow{9}{*}{2.768} & \multirow{9}{*}{17.30} & \multirow{6}{*}{$\begin{array}{cccc}\text { 剔 出後 } & 14 & \text { 日 } & \text { 目 } \\
\text { " } & 15 & \text { 日 } & \text { 目 } \\
\text { " } & 16 & \text { 日 } & \text { 目 } \\
\text { " } & 17 & \text { 日 } & \text { 目 }\end{array}$} \\
\hline $25 / 11$ & 1890 & 204 & 0.384 & 0.736 & & & & \\
\hline $26 / / 1$ & 1915 & 190 & 0.499 & 0.957 & & & & \\
\hline $27 / 11$ & 1900 & 180 & 0.479 & 0.918 & & & & \\
\hline $28 / \prime \prime$ & 1910 & 164 & 0.335 & 0.642 & & & & \\
\hline 平均 & & & 0.424 & 0.801 & & & & \\
\hline $29 /$ VIII & $\mid 1885$ & 184 & 3.516 & 6.740 & & & & インドール16ing注射 \\
\hline $30 / \prime \prime$ & 1895 & 162 & 0.456 & 0.874 & & & & \multirow{2}{*}{$\begin{array}{cccc}\text { 剔 出後 } & 19 & \text { 日 } & \text { 目 } \\
\text { " } & 20 & \text { 日 } & \text { 目 }\end{array}$} \\
\hline $31 / / 1$ & 1910 & 162 & 0.482 & 0.924 & & & & \\
\hline $1 / I X$ & $\mid 1900$ & 182 & 0.296 & 0.567 & \multirow{7}{*}{5.183} & \multirow{7}{*}{2.415} & \multirow{7}{*}{15.09} & \multirow{2}{*}{$\begin{array}{c}\text { プロラン } 1 \text { c.c. 注射 } \\
\text { / }\end{array}$} \\
\hline $2 / / 1$ & 1905 & 158 & 0.249 & 0.477 & & & & \\
\hline $3 / 11$ & 1915 & 174 & 0.335 & 0.642 & & & & " \\
\hline $4 / "$ & 1920 & 194 & 0.494 & 0.947 & & & & $" 1$ \\
\hline 平均 & & & 0.344 & 0.658 & & & & \multirow{3}{*}{$\begin{array}{l}\text { インドール16 mg 及ビ } \\
\text { プロラン } 1 \text { c.c. 注射 } \\
\text { プロラン } 1 \text { c.c. 注射 }\end{array}$} \\
\hline $5 / 1 X$ & 1885 & 168 & 3.047 & 5.841 & & & & \\
\hline $6 / 11$ & 1900 & 178 & 0.291 & 0.558 & & & & \\
\hline $7 / I X$ & $\mid 1900$ & 188 & 0.564 & 1.081 & \multirow{7}{*}{4.748} & \multirow{7}{*}{2.213} & \multirow{7}{*}{13.83} & \multirow{3}{*}{$\begin{array}{c}\text { プロラン } 1 \text { c.c. 注射 } \\
\text { " } \\
\text { " }\end{array}$} \\
\hline $8 / 11$ & 1905 & 150 & 0.720 & 1.380 & & & & \\
\hline $9 / 11$ & 1895 & 168 & 0.697 & 1.336 & & & & \\
\hline 本均 & & & 0.660 & 1.266 & & & & \multirow{4}{*}{ 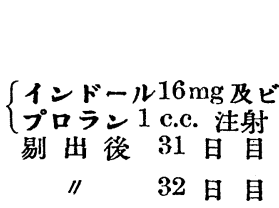 } \\
\hline $10 / 1 X$ & $\mid 1920$ & 176 & 3.137 & 6.014 & & & & \\
\hline $11 / /$ & 1925 & 173 & 0.636 & 1.219 & & & & \\
\hline $12 / " /$ & 1930 & 182 & 0.823 & 1.578 & & & & \\
\hline
\end{tabular}

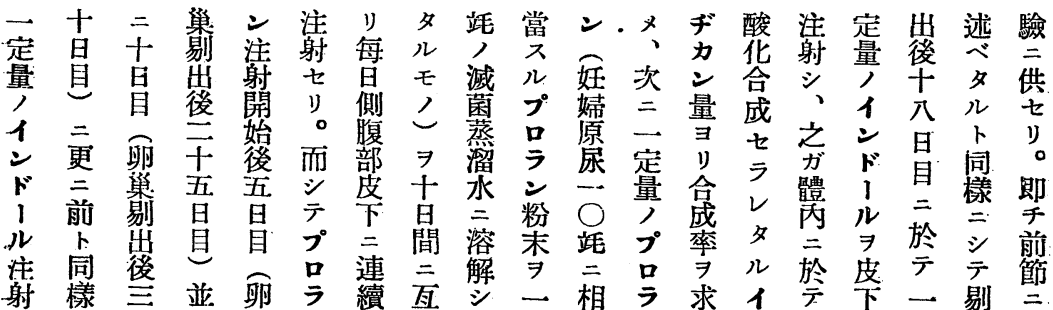


第十一表 卵巢剔出成熟家鬼プロラン連續注射（第二例）

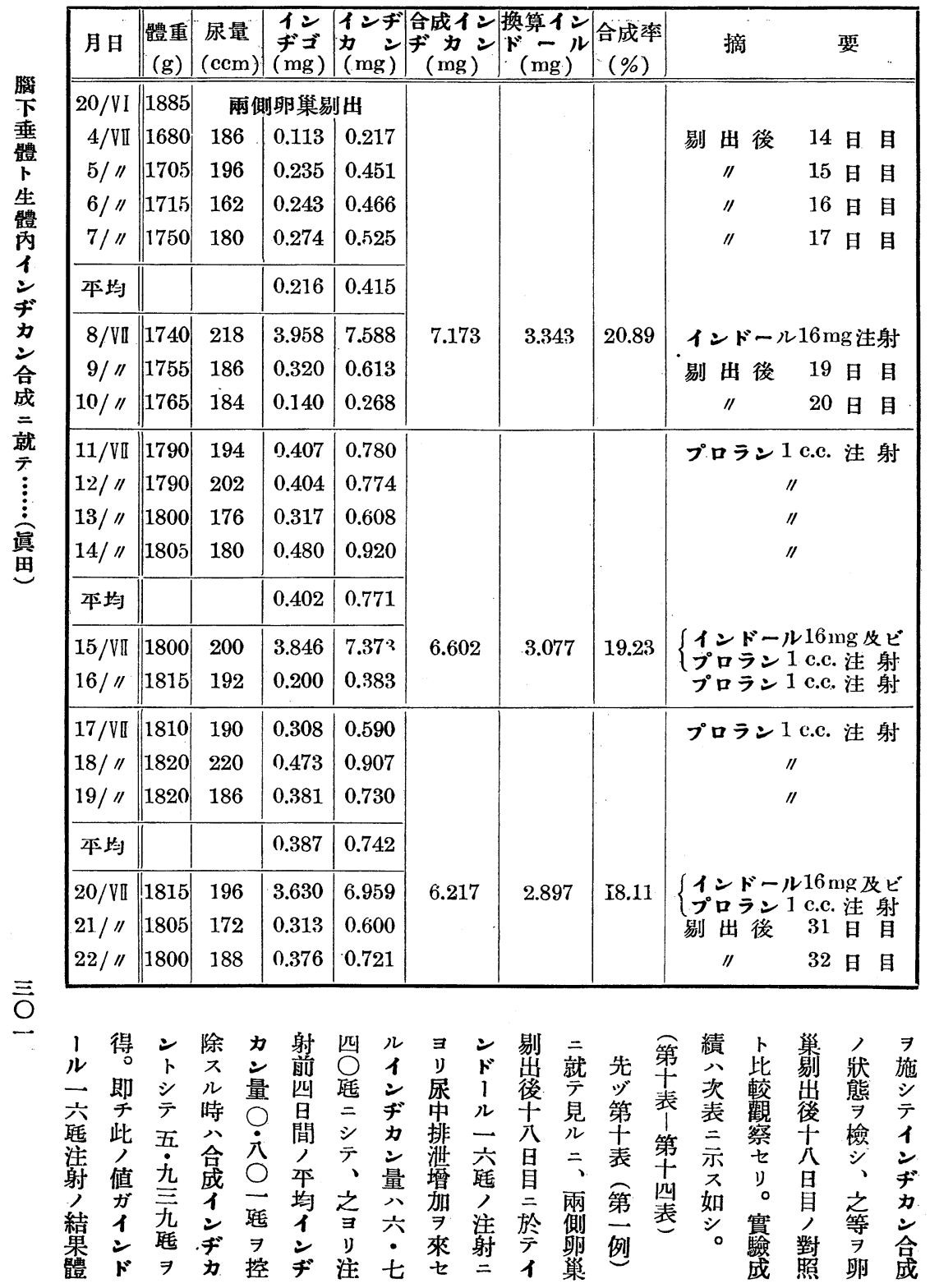


第十二表 卵巢剔出成熟家鬼プロラン連續注射（第三例）

\begin{tabular}{|c|c|c|c|c|c|c|c|c|}
\hline 月日 & \begin{tabular}{|c|}
$\mid \begin{array}{c}\text { 體重 } \\
(\mathrm{g})\end{array}$ \\
\end{tabular} & $\begin{array}{l}\text { 尿量 } \\
(\mathrm{ccm})\end{array}$ & 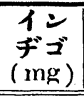 & $\begin{array}{l}\text { 1ンヂ } \\
\text { カ } \\
(\mathrm{mg})\end{array}$ & 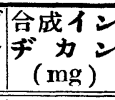 & 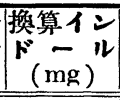 & 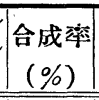 & 摘 \\
\hline $10 /$ VIII & $\mid 2115$ & \multicolumn{3}{|c|}{ 兩側卯集剔出 } & \multirow{9}{*}{6.707} & \multirow{9}{*}{3.126} & \multirow{9}{*}{19.54} & \multirow{6}{*}{$\begin{array}{cccc}\text { 剔 出 後 } & 14 & \text { 日 } & \text { 目 } \\
\text { " } & 15 & \text { 日 } & \text { 目 } \\
\text { " } & 16 & \text { 日 } & \text { 目 } \\
\text { " } & 17 & \text { 日 } & \text { 目 }\end{array}$} \\
\hline $24 / "$ & 1910 & 172 & 0.238 & 0.456 & & & & \\
\hline $25 / 11$ & 1900 & 168 & 0.137 & 0.263 & & & & \\
\hline $26 / " 1$ & $\mid 1890$ & 216 & 0.249 & 0.477 & & & & \\
\hline $27 / /$ & $\mid 1915$ & 160 & 0.312 & 0.598 & & & & \\
\hline 平均 & & & 0.234 & 0.449 & & & & \\
\hline $28 / \mathrm{VIII}$ & $\mid 1895$ & 168 & 3.733 & 7.156 & & & & インドール16mg注射 \\
\hline $29 / 11$ & 1905 & 180 & 0.635 & 1.217 & & & & \multirow{2}{*}{ 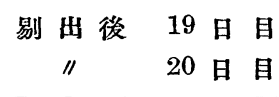 } \\
\hline $30 / / 1$ & 1890 & 160 & 0.677 & 1.298 & & & & \\
\hline $31 / \mathrm{VII}$ & $\mid 1910$ & 162 & 0.486 & 0.932 & \multirow{7}{*}{6.854} & \multirow{7}{*}{3.194} & \multirow{7}{*}{19.96} & \multirow{2}{*}{$\begin{array}{c}\text { プロラン } 1 \text { c.c. 注 射 } \\
\|\end{array}$} \\
\hline $1 / I X$ & 1920 & 174 & 0.594 & 1.139 & & & & \\
\hline $2 / 11$ & 1910 & 182 & 0.610 & 1.169 & & & & "I \\
\hline $3 / 1 /$ & 1915 & 192 & 0.576 & 1.104 & & & & " \\
\hline 平均 & & & 0.567 & 1.086 & & & & \multirow{3}{*}{$\begin{array}{l}\text { インジール16 mg 及ビ } \\
\text { プロラン } 1 \text { c.c. 注 射 } \\
\text { プロラン } 1 \text { c.c. 注 射 }\end{array}$} \\
\hline $4 / I X$ & 1920 & 160 & 4.142 & 7.940 & & & & \\
\hline $5 / 11$ & $\mid 1890$ & 178 & 0.758 & 1.453 & & & & \\
\hline $6 / I X$ & $\mid 1900$ & 168 & 0.593 & 1.127 & \multirow{7}{*}{6.371} & \multirow{7}{*}{2.969} & \multirow{7}{*}{18.56} & \multirow{3}{*}{$\begin{array}{c}\text { プロラン } 1 \text { c.c. 注 射 } \\
\text { " } \\
" 1\end{array}$} \\
\hline $7 / 1 /$ & 1905 & 188 & 0.702 & 1.346 & & & & \\
\hline $8 / 11$ & 1895 & 174 & 0.603 & 1.156 & & & & \\
\hline 平均 & & & 0.633 & 1.213 & & & & \multirow{4}{*}{ 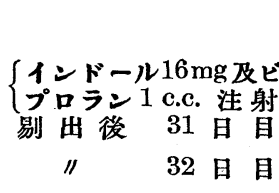 } \\
\hline $9 / I X$ & 1930 & 178 & 3.956 & 7.484 & & & & \\
\hline $10 / / 1$ & 1905 & 180 & 0.652 & 1.250 & & & & \\
\hline $11 / "$ & 1925 & 174 & 0.438 & 0.840 & & & & \\
\hline
\end{tabular}

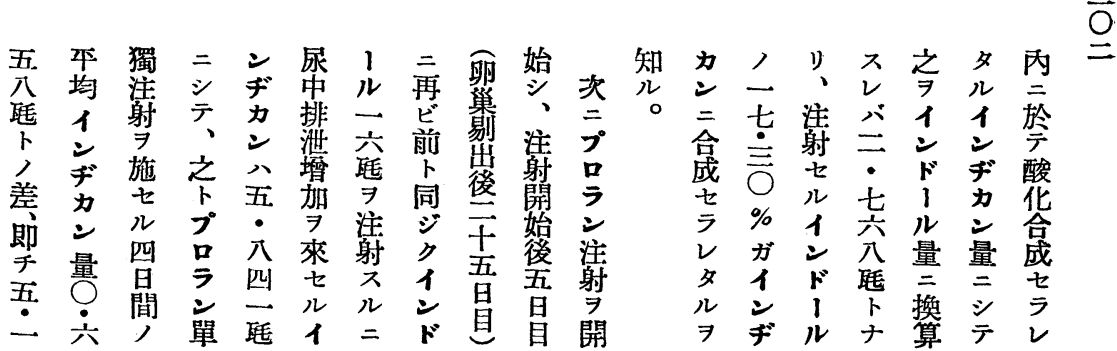


第十三表 卵巢剔出成熟家鬼プロラン連續注射（第四例）

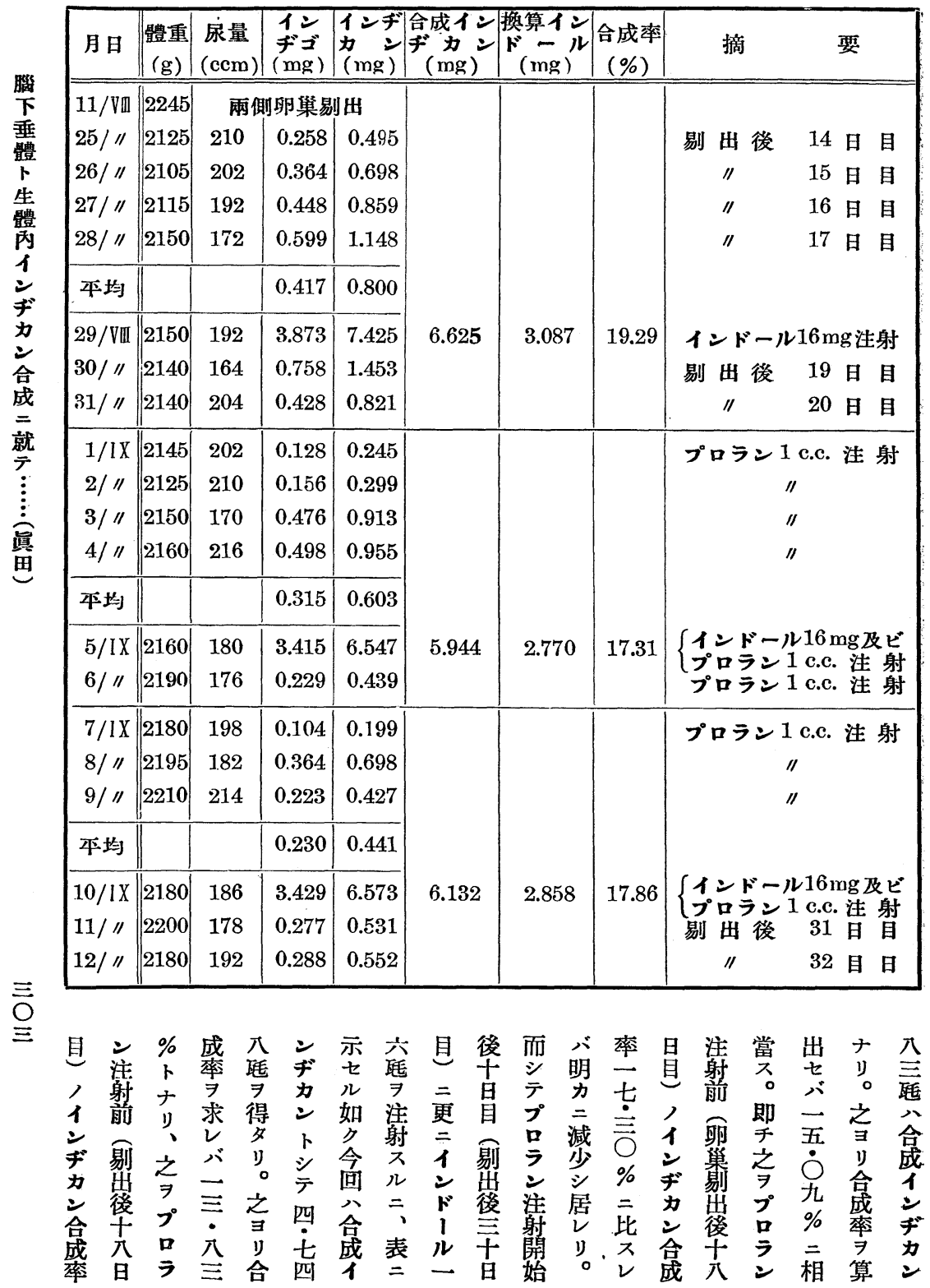


第十四 表卵巢剔出成熟家鬼プロラン連續注射（第五例）

\begin{tabular}{|c|c|c|c|c|c|c|c|c|}
\hline 月日 & $\mid \begin{array}{l}\mid \begin{array}{l}\text { 體重 } \\
(\mathrm{g})\end{array} \\
\end{array}$ & $\begin{array}{l}\text { 尿量 } \\
(\mathrm{ccm})\end{array}$ & $\begin{array}{l}\text { 1ン } \\
\text { F゙ゴ } \\
(\mathrm{mg})\end{array}$ & $\begin{array}{l}\text { 1ンデ } \\
\text { カ2 } \\
(\mathrm{mg})\end{array}$ & 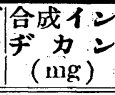 & $\begin{array}{l}\text { F奐算イン } \\
\text { (mg) }\end{array}$ & 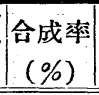 & 摘 \\
\hline $11 /$ VII & 1950 & \multicolumn{3}{|c|}{ 兩側卵巢剔出 } & \multirow{9}{*}{6.356} & \multirow{9}{*}{2.962} & \multirow{9}{*}{18.51} & \multirow{6}{*}{ 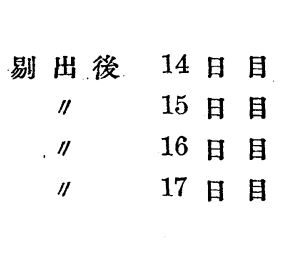 } \\
\hline $.25 / 11$ & 1790 & 192 & 0.488 & 0.936 & & & & \\
\hline $26 / 1 /$ & 1780 & 176 & 0.554 & 1.062 & & & & \\
\hline $27 / 1 /$ & 1775 & 168 & 0.474 & 0.909 & & & & \\
\hline $28 / .11$ & 1795 & 184 & 0.650 & 1.246 & & & & \\
\hline 平均 & & & 0.542 & 1.038 & & & & \\
\hline $29 /$ VII & 1780 & 194 & 3.857 & 7.394 & & & & インドール16mg注射 \\
\hline $30 / / 1$ & 1770 & 174 & 0.548 & 1.051 & & & & \multirow{2}{*}{$\begin{array}{cccc}\text { 剔 出 後 } & 19 & \text { 日 } & \text { 目 } \\
\text { " } & 20 & \text { 日 } & \text { 目 }\end{array}$} \\
\hline $31 / "$ & 1785 & 166 & 0.320 & 0.613 & & & & \\
\hline $1 / I X$ & 1765 & 174 & 0.339 & 0.650 & \multirow{7}{*}{5.582} & \multirow{7}{*}{2.601} & \multirow{7}{*}{16.26} & \multirow{2}{*}{ プロラン 1 c.c. 注 射 } \\
\hline $2 / / 1$ & 1790 & 182 & 0.494 & 0.947 & & & & \\
\hline $3 / / 1$ & 1800 & 194 & 0.551 & 1.056 & & & & " \\
\hline $4 / / 1$ & 1825 & 162 & 0.456 & 0.874 & & & & " \\
\hline 平均 & & & 0.460 & 0.882 & & & & \multirow{3}{*}{$\begin{array}{l}\text { インドール } 16 \mathrm{mg} \text { 及ビ } \\
\text { プロラン } 1 \text { c.c. 注 射 } \\
\text { プロラン } 1 \text { c.c. 注 射 }\end{array}$} \\
\hline $5 / 1 X$ & 1810 & 206 & 3.372 & 6.464 & & & & \\
\hline $6 / 11$ & 1830 & 198 & 0.515 & 0.987 & & & & \\
\hline $7 / I X$ & $\mid 1835$ & 192 & 0.263 & 0.504 & \multirow{7}{*}{5.488} & \multirow{7}{*}{2.557} & \multirow{7}{*}{15.98} & \multirow{3}{*}{$\begin{array}{c}\text { プロラン } 1 \text { c.c. 注 射 } \\
\| \\
\|\end{array}$} \\
\hline $8 / / 1$ & 1835 & 170 & 0.513 & 0.983 & & & & \\
\hline $9 / / /$ & 1845 & 198 & 0.455 & 0.872 & & & & \\
\hline 平均 & & & 0.410 & 0.786 & & & & \multirow{4}{*}{ 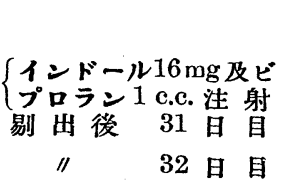 } \\
\hline $10 / I X$ & 1820 & 196 & 3.273 & 6.274 & & & & \\
\hline $11 / / "$ & 1840 & 160 & 0.546 & 1.047 & & & & \\
\hline $12 / / \prime$ & 1835 & 182 & 0.391 & 0.750 & & & & \\
\hline
\end{tabular}

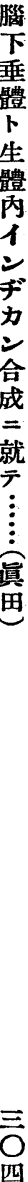

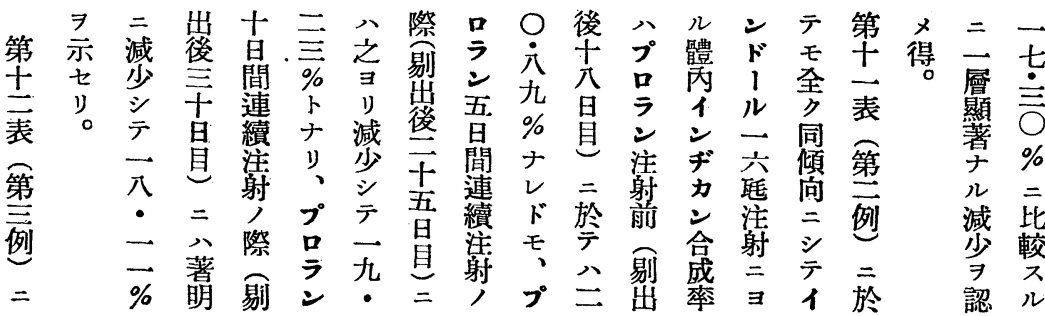




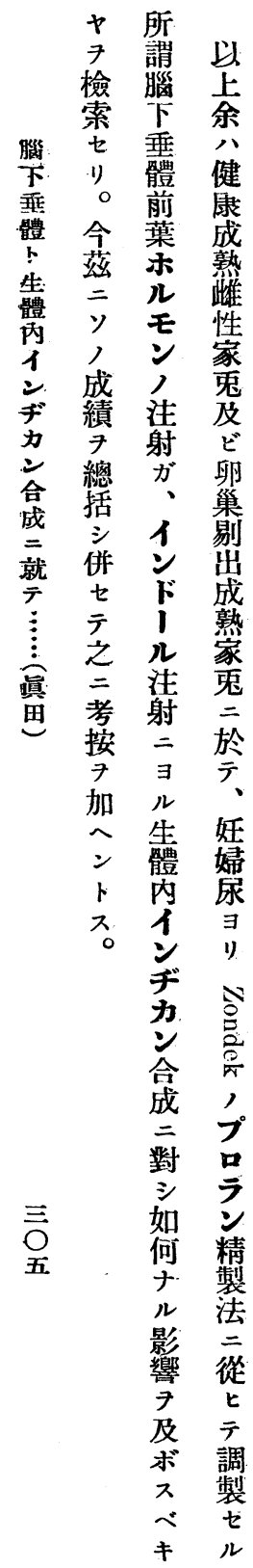

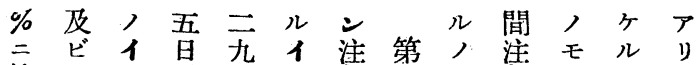

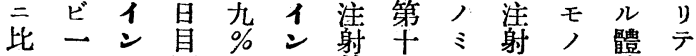

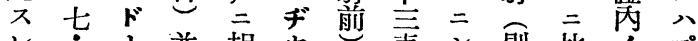
六 1 並相力表严剔此 170 共六注市當公於第殆出後テ方

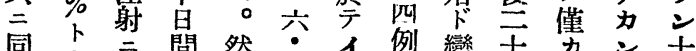

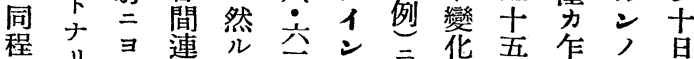

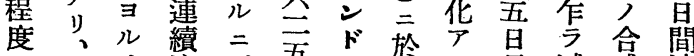

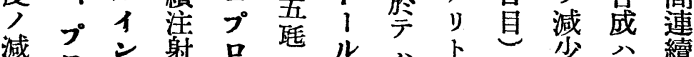
第減 プン射口起ル人ト少 續 四 少

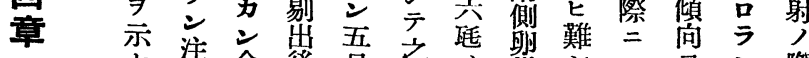

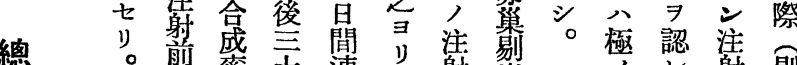

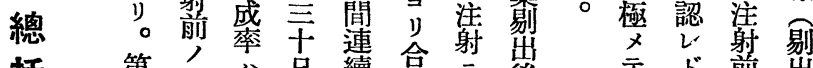
括 第該 公續威亖後宁ド前出

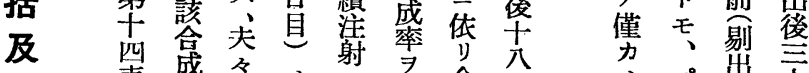

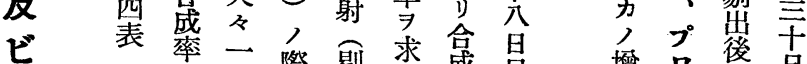
考 第 按 吾立三合後

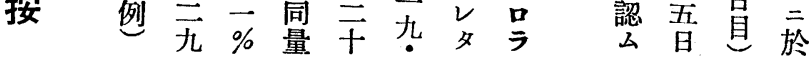

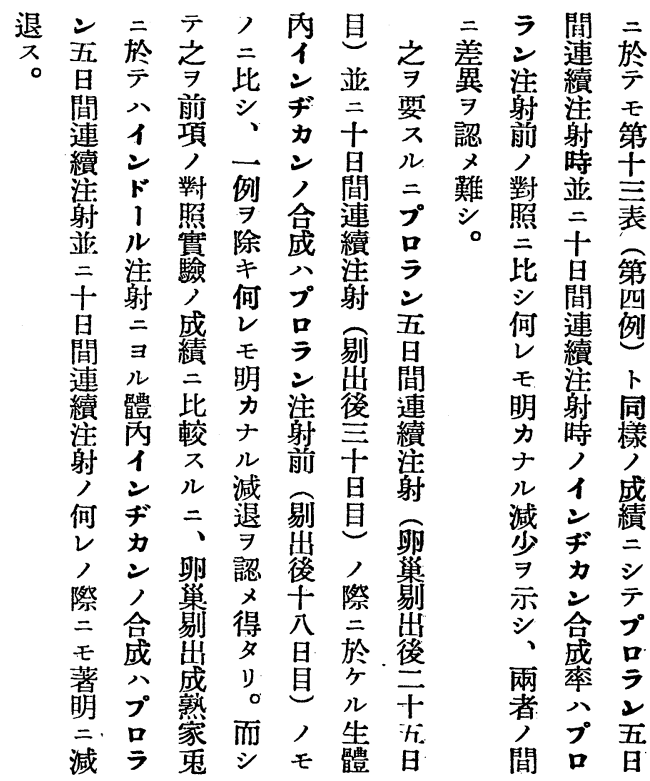




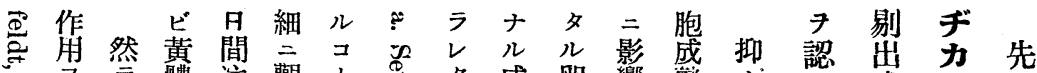
Ð 檢 バ體 注 觀

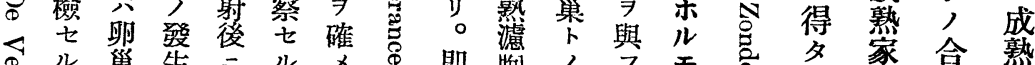

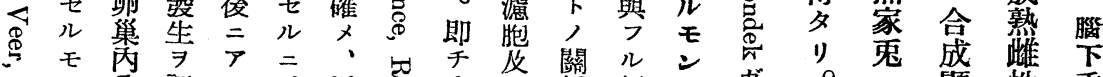

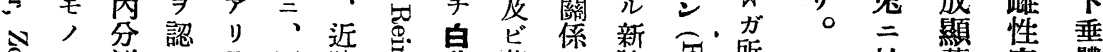

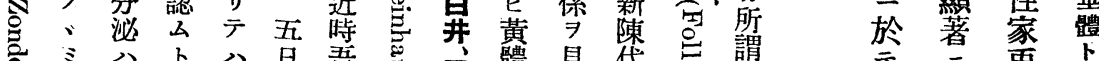

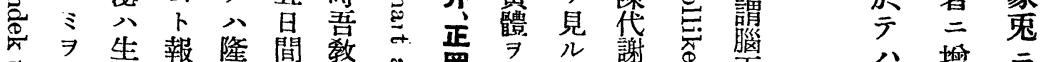

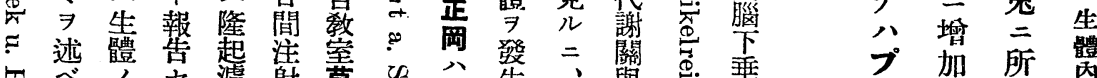

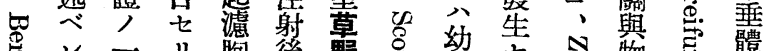

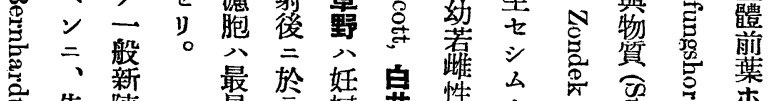

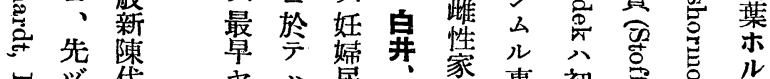

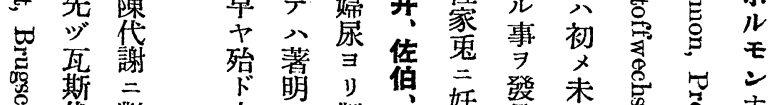

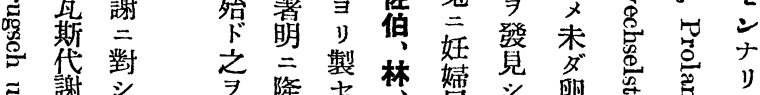

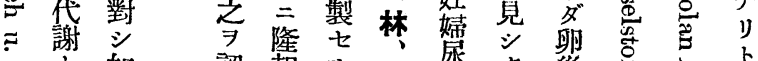

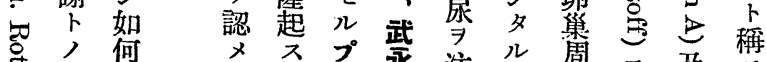
滎關何 ザ

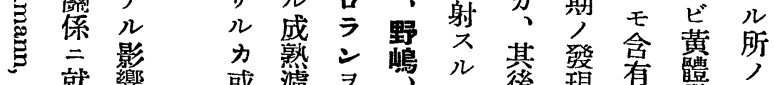

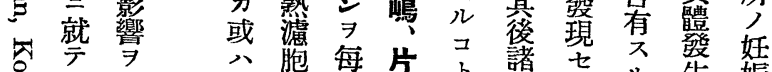

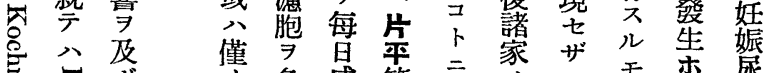
壳范梁多成等

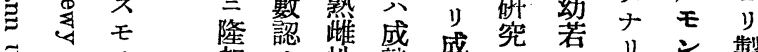

₹

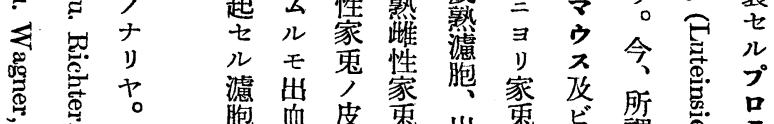

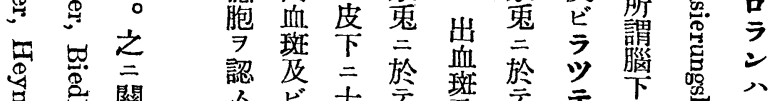

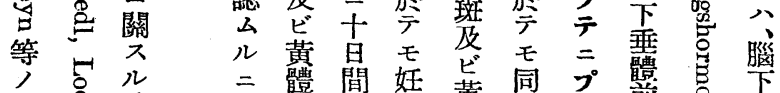

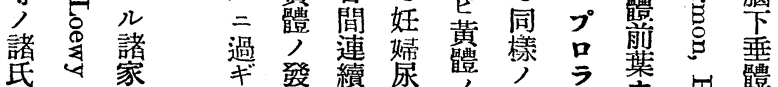

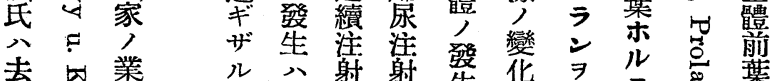

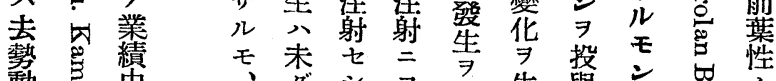

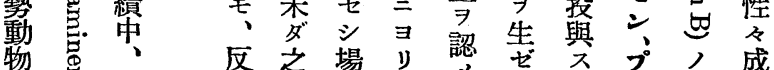

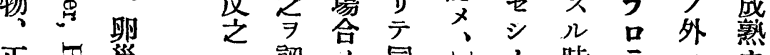

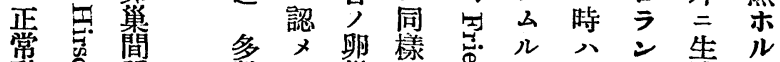

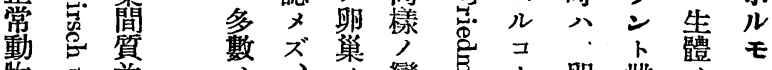
努三亚

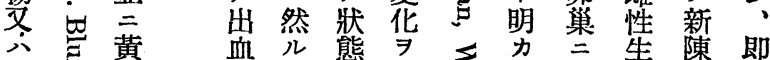

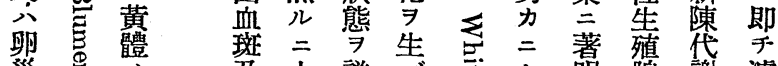

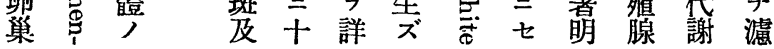

ラ $レ$ 晒

五无垂出

日十體方

間白前合 連。間葉成

續連 ホ 就

注續 ル

射注正射

二

十際 プ 思

日 $=$ 口

閐

連之

注反連

射 シ 續

何门注

ᄂ 2

ノ ヂル

際力 二

モ五

1 合 日

成 間

ヂ明連

カ力續 三

$v$ 二注

) 減 射

盒退祭

成 七際

意。”

二 然 生

減 ル 體

弱二內

七 卵 1

ル集 


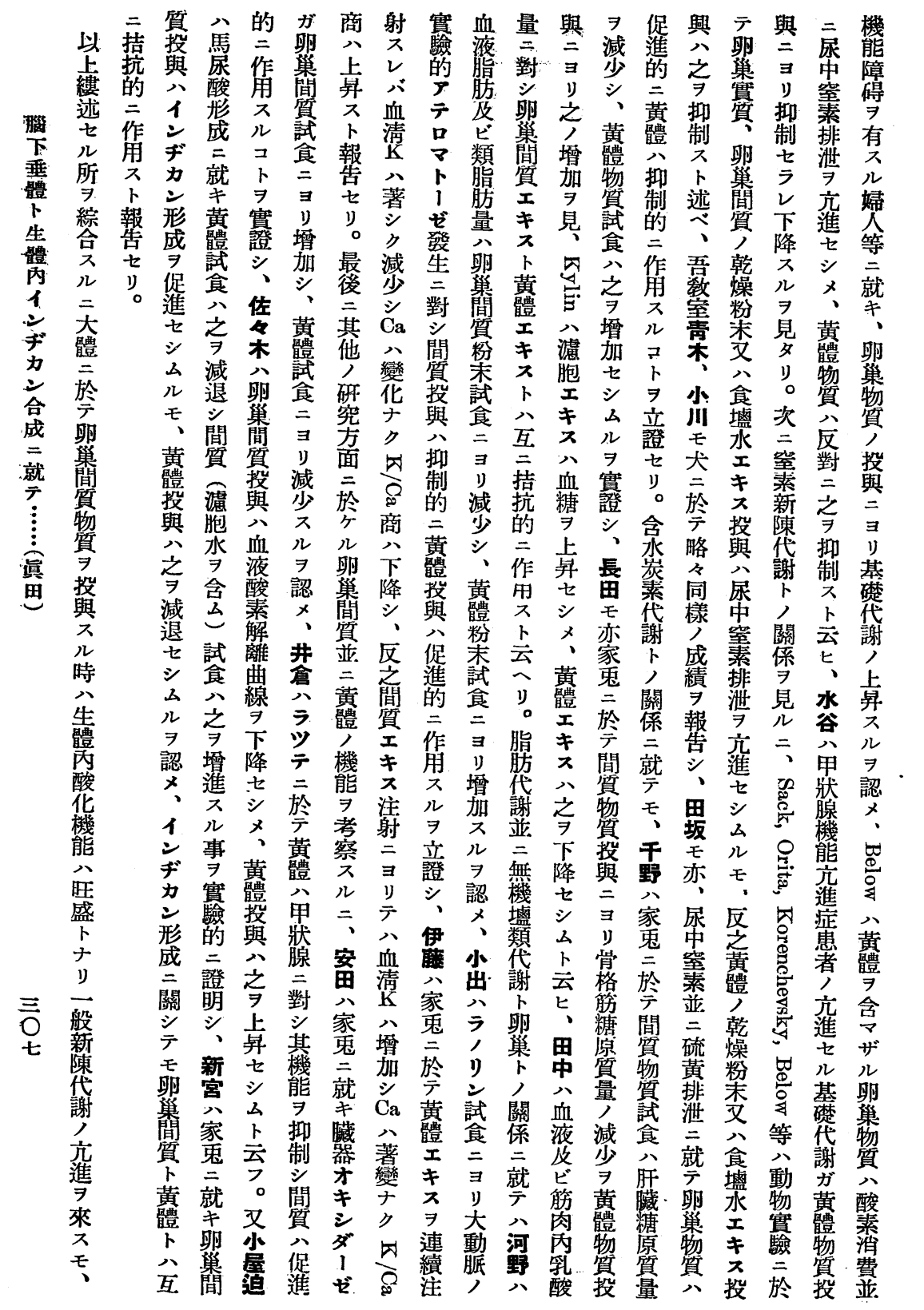




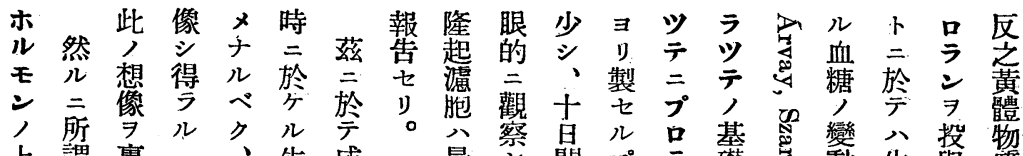

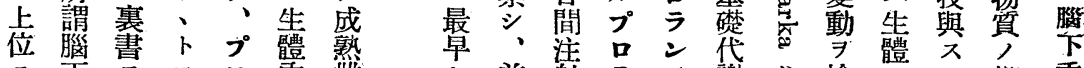

三下坴コ呙踓市前射

立垂ルロライ性殆者後ン連分卯燓新場與體

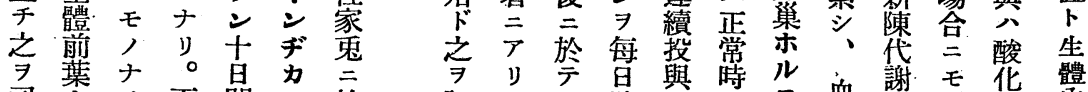

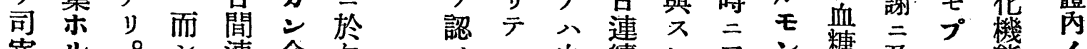

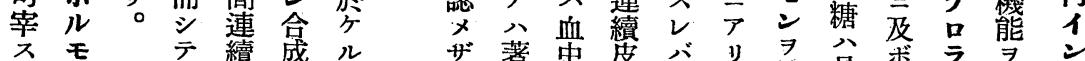

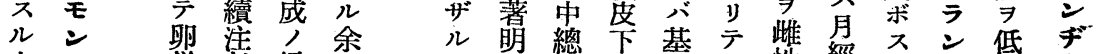

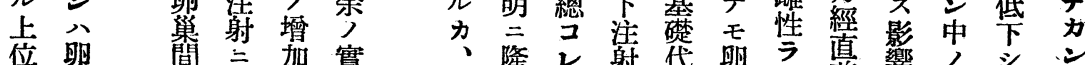

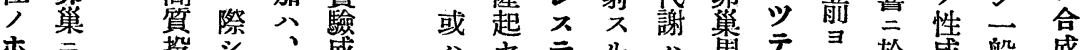

ホ主慟 與

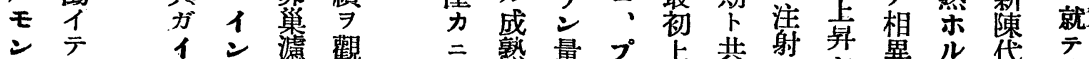

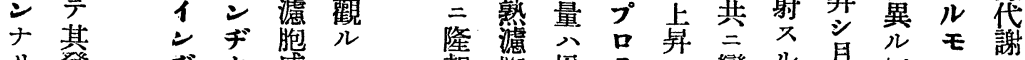

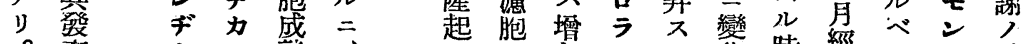

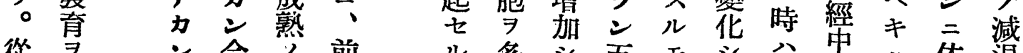

從 $尹$ 合前

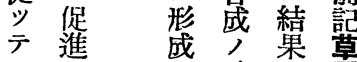

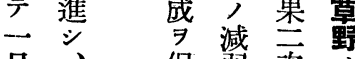

旦、促弱宁,

留其進 $尹$ 的啹

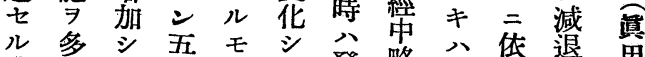

濾數血日次、發略垒售退思

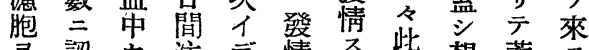

$\Rightarrow$ 認力注 $テ$

認么ル射下前儿值像起モ

ムルシ後降期卡㑺不七,

ルモウ严持ルラテ

$\Rightarrow$ 菓 晕 新卜

・剔發體 ル陳其

出㥽 投 與黃謝 軦

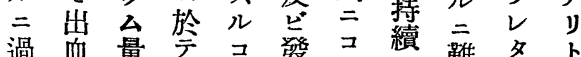

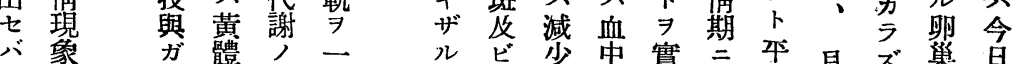

例表 省簦雀

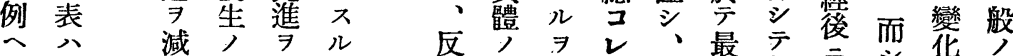

プ 退之來 $\exists$ 之發認

ラ

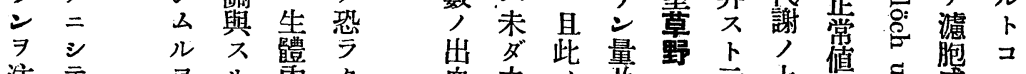

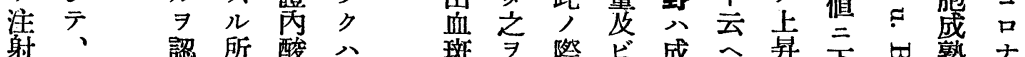

射、認所酸八瑟 $\rightrightarrows$ 際 ビ成会年若熟ナ

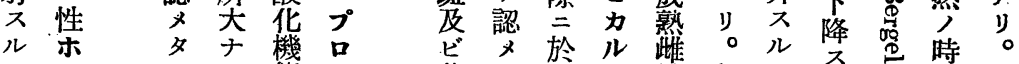

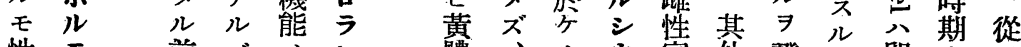

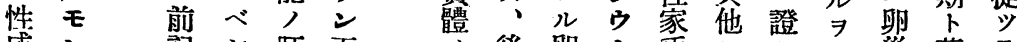

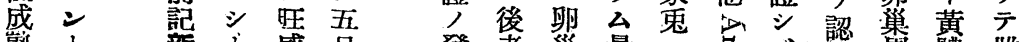

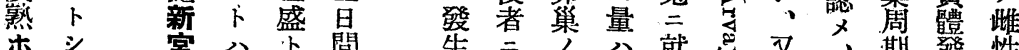

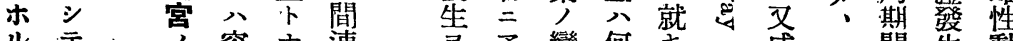

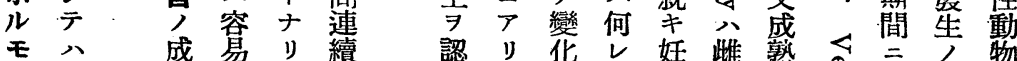

モ 卯 盛易 シ 續 認

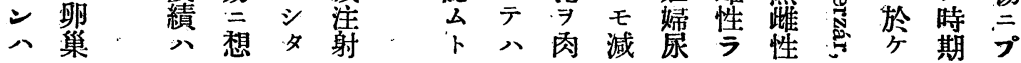




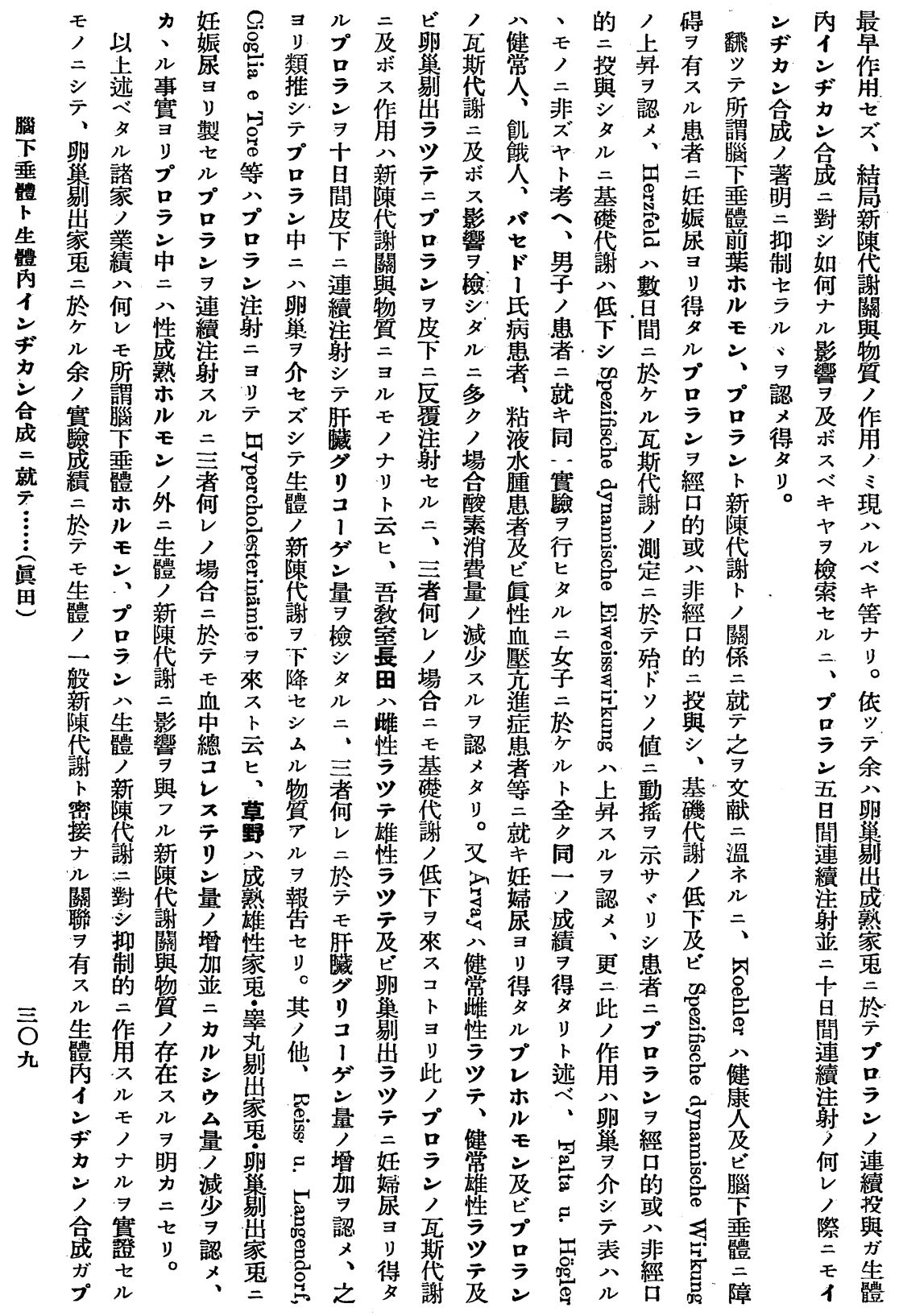


二三洼: 檢 诚 卵射成索主 退巢 熟 シ ヂ健 ス剔際雌、力康 即出成心家, 次威 于 熟之兔如合 蹗 プ 家三三キ成性

鬼 反於結 分家

ラ三浪論、兔 於 1 八 7 妊鬼

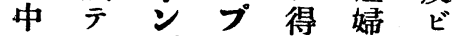
二八乔品尿蛊 八ブカラリヨ巢 卵口斗》剔

巢, 五製出 7 合 介五成 間 七昌明連

ズ 間 力 續

シ 連 二 注

テ續 減 射

生 注 退 體射亚寻

内並。少

1

ヂ 日

カ 間

ン 連

合 續

成 注

二 射

影

響 何

藇

今 際

ル

物

質: 加

在 ゚ ス

ス デ然

カ

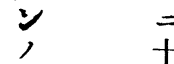

弇旦

咸間

萌
七 成

ル 熟

所家

謂 鬼

腦 三

下於

垂 テ

體 生體

禾 解

ル 毒

モ 作

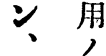

プ 一

口 r

亏 乇

見

做

注 $\pi$

射 べ

$\begin{array}{ll}= & \neq \\ \exists & 1\end{array}$

如 $\mathfrak{F}$

何

影 洼

響 射

七

ラ

ㄱ.
葉 解

ヤ能

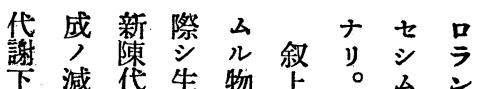

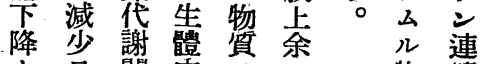
卜 $\rightarrow$ 關内, 分物續

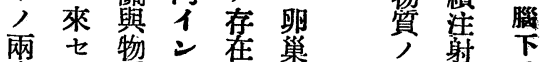
者ル賀デス剔在

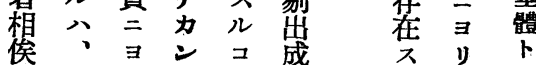
此号拿卢篦公明生

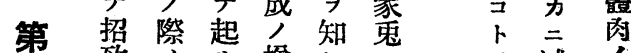
五致分增 $2=\exists$ 減 1

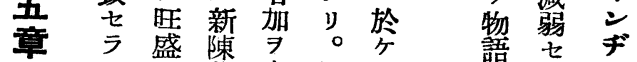

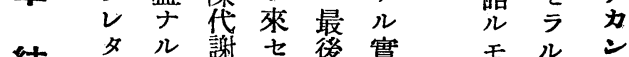

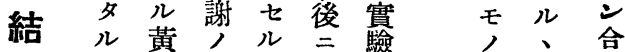

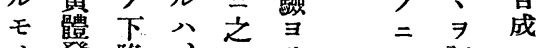
發降非悲認三 ナ生度此基所 テ 諒

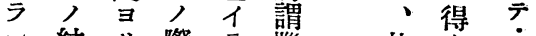

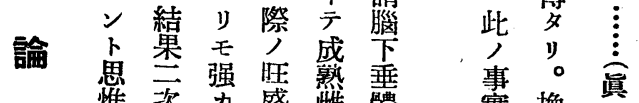

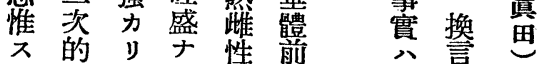
$=シ ル 2$ 家葉 前 起二濾鬼采記

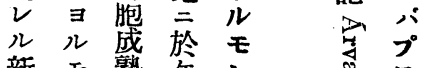

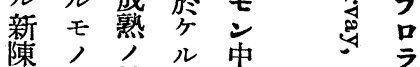
䄩广結余吕 謝儿果, 公䍃市

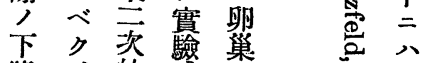
降、的成斗量卵 プ プ 績介 镸㓯

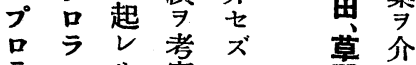

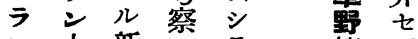
ン十新尔テ等 ズ 中昆陳生著

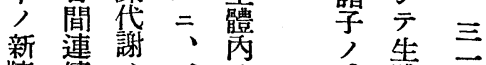

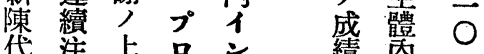
帒集品績丙

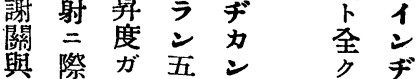

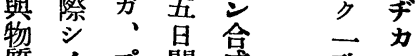

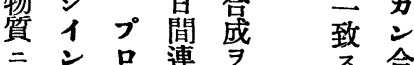
$=2$ 連 7 合 ヨデラ續減公成 儿力注弱籍 新六中射艺 陳 合, 射悉录抑 


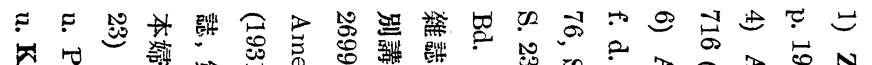

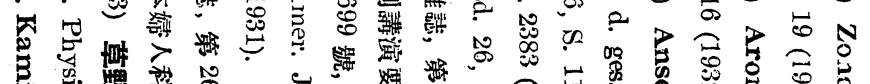

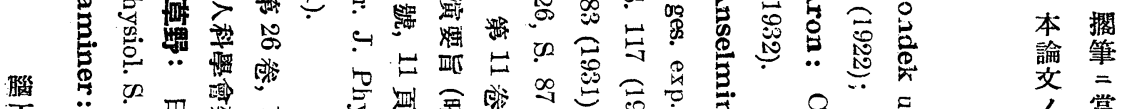

下 .

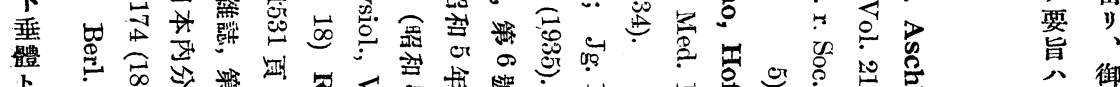

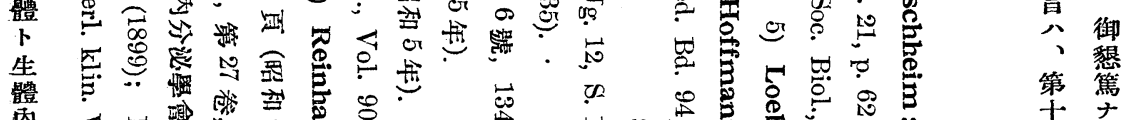

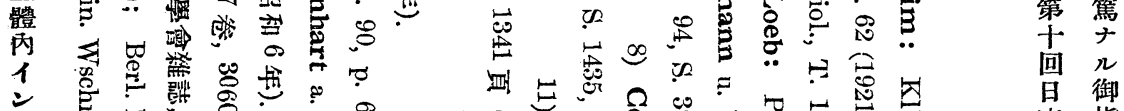

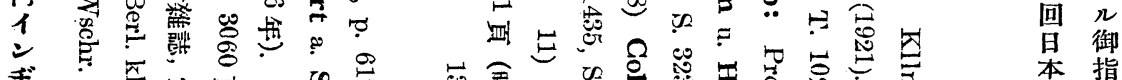

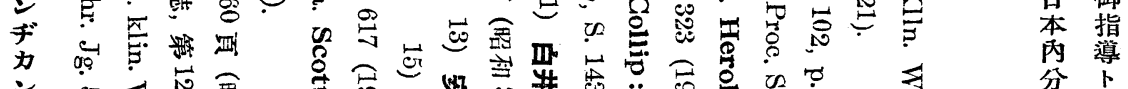

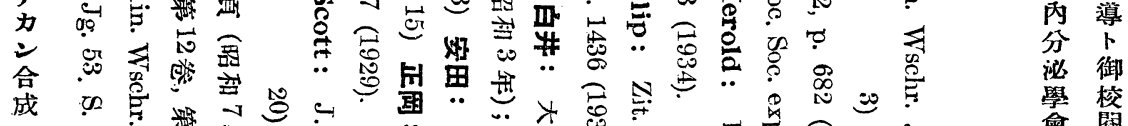

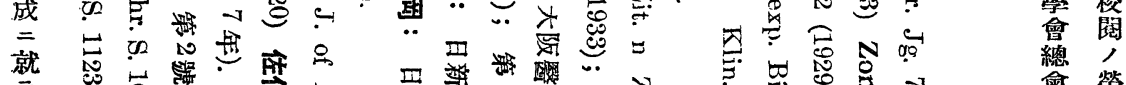

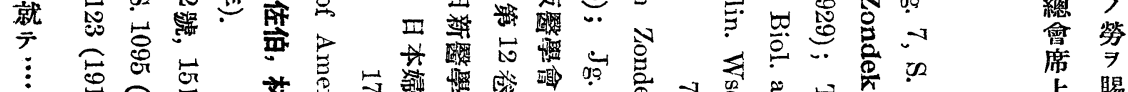

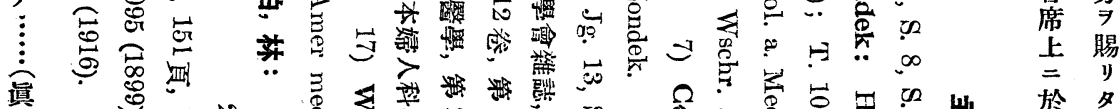

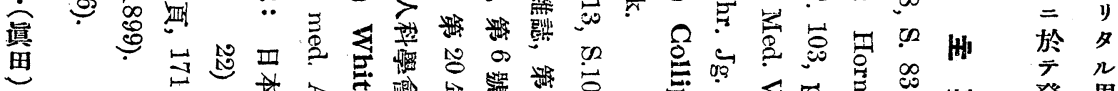

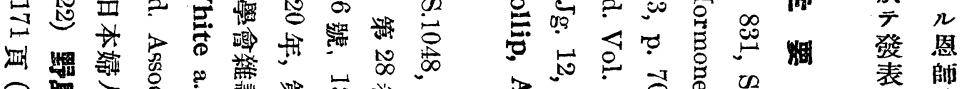

N

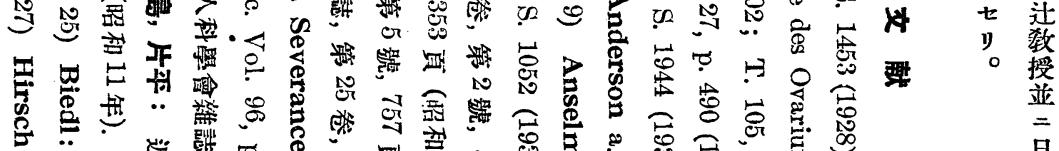

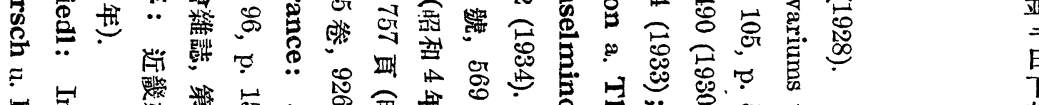

焉志 整

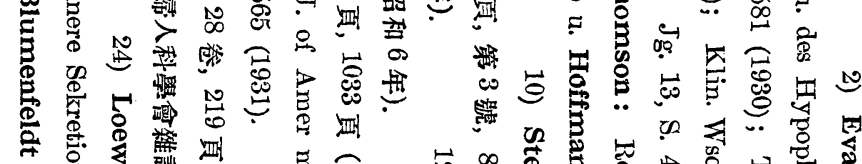

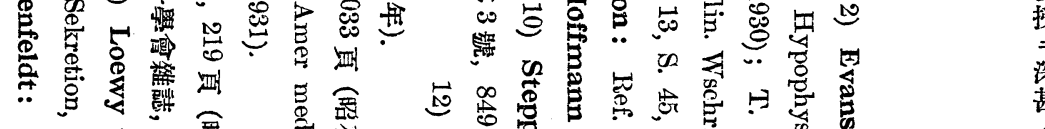

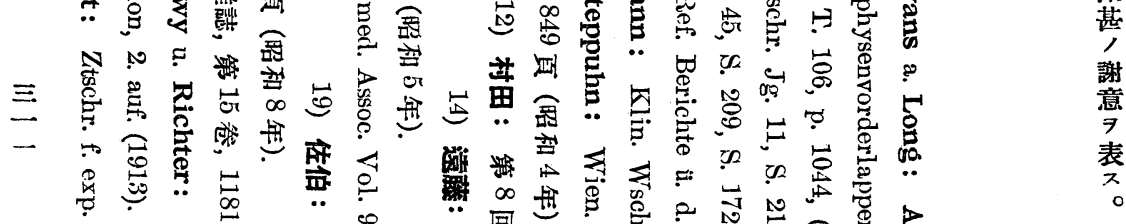

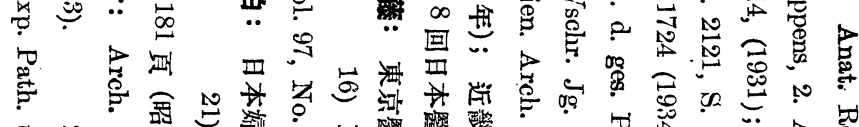

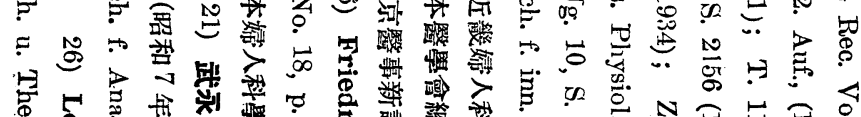

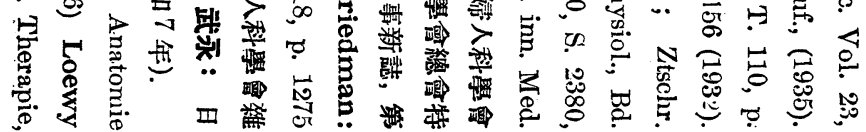




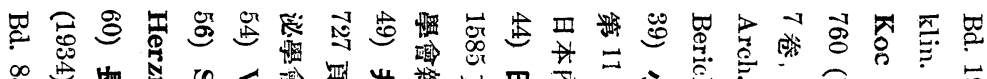

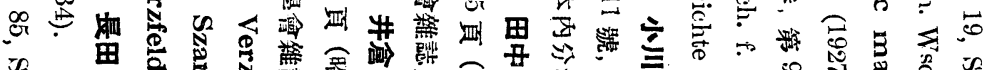

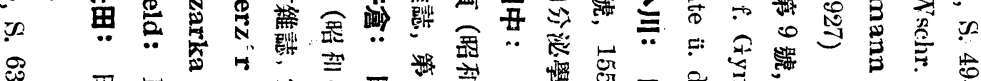

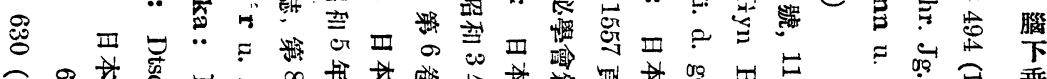

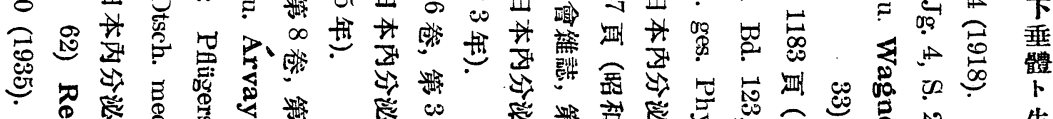

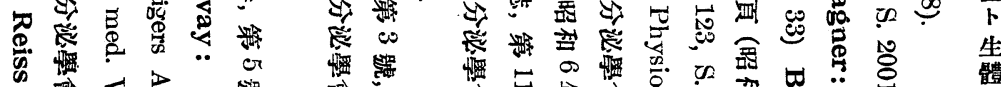

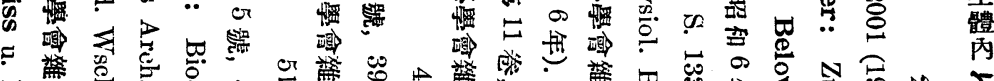

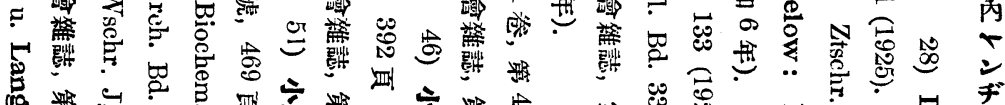

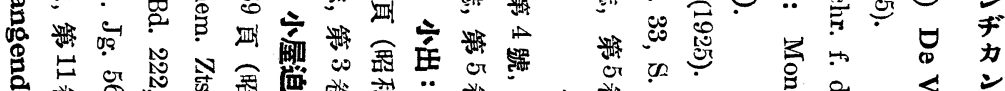

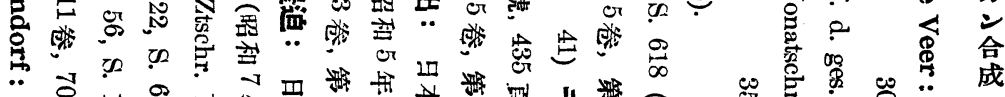

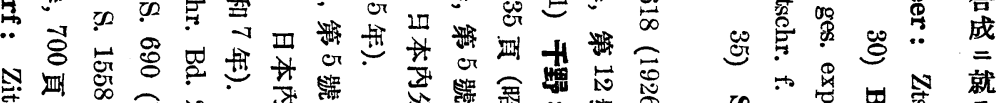

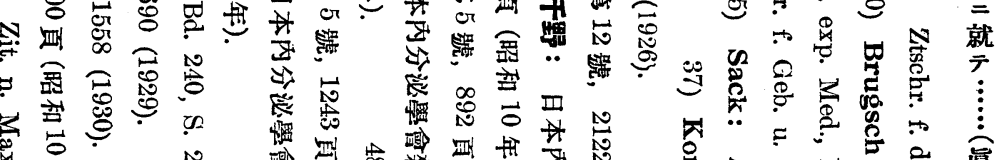

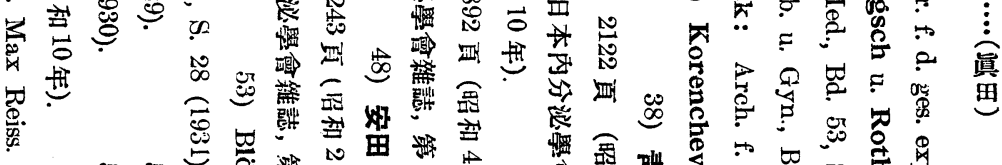
舟

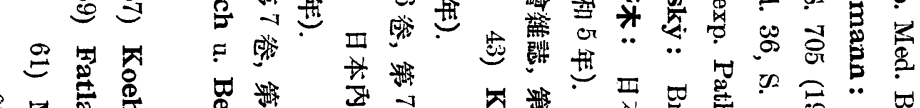

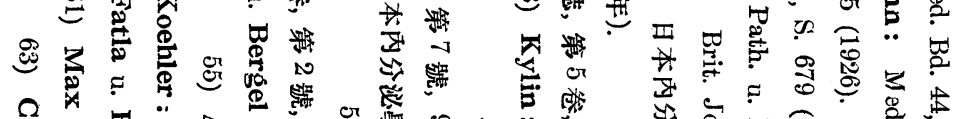

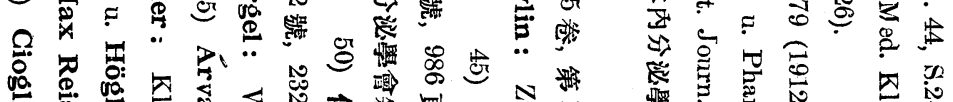

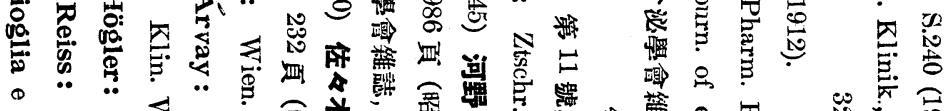

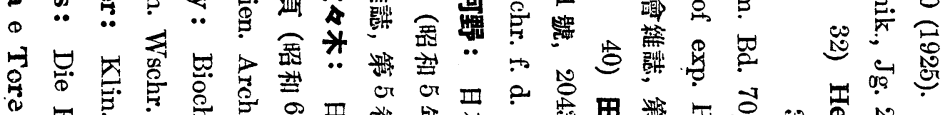
․

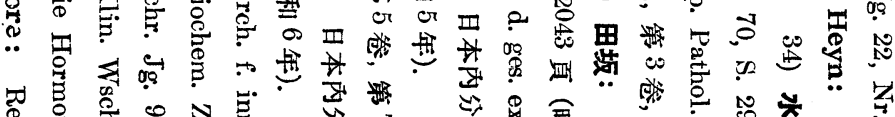

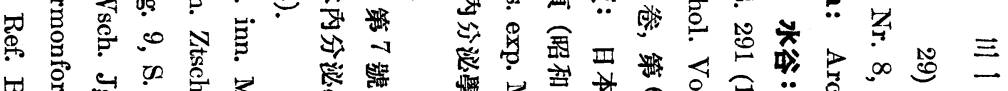

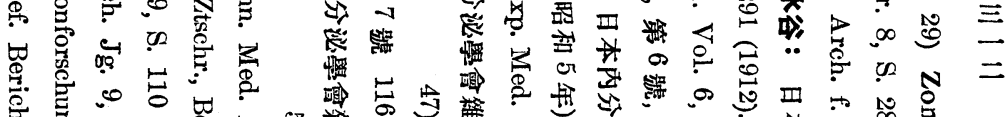

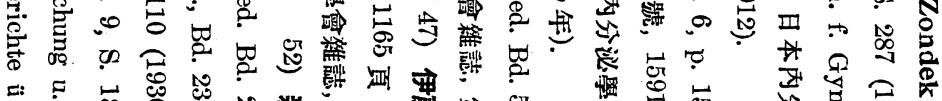

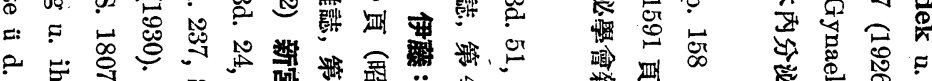

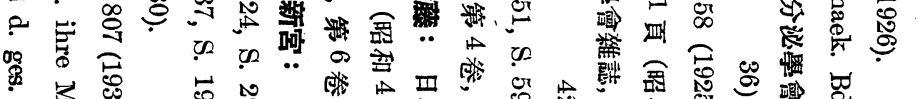

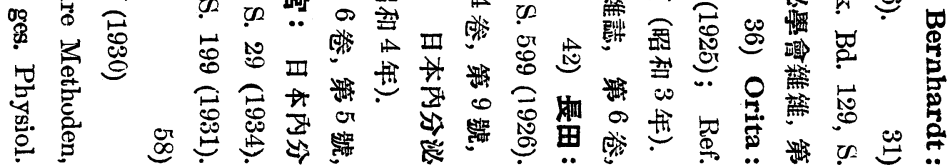


2) Bei mit Hypophysenvorderlappen- Nacl- extrakt injizierten Kaninchen erscheint das injizierte Indol als Indican im Urin deutlicher als bei den Kontrollen.

3) Bei mit Pituitrin injizierten Kaninchen nimmt die Ausscheid ung des Indicans nach Indolinjektion im Urin ausgesprochen ab. (Autoreferat)

\title{
Über die Beziehung zwischen der Indicansynthese im Organismus und der Hypophyse.
}

\section{Mitteilung. \\ Über den Einfluss des sogenannten Hypophysenvorderlappenhormons bei weiblichen Kaninchen.}

\author{
Von
}

\section{Dr. E. Sanada.}

(Aus der 1. Med. Klinik der Kaiserl. Universität za Kyoto in Japan. Direktor : Prof. Dr. K. Tsuji)

In dieser Mitteilung untersuchte der Verfasser den Einfluss wiederholter Injektion des sogenannten Hypophysenvorlappenhormons, d. h. des Prolans auf die Indicansynthese bei der Indolinjektion am erwachsenen weiblichen sowie am ovariektomierten Kaninchen.

Das Prolan wurde nach dem Zondekschen Verfahren aus dem Harn von Schwangeren hergestellt.

Die Ergebnisse lassen sich folgendermassen zusammenfassen :

1) Bei erwachsenen weiblichen Kaninchen nahm durch die täglich einmal 5 Tage lang durchgeführte Injektion des Prolans die Ausscheidung des Indicans nach der Indolinjektion im Urin ausgesprochen zu. Dagegen führte die täglich einmal 10 Tage lang durchgeführte Injektion des Prolans zur Verminderung der Indicanausscheidung im Urin.

2) Bei ovariektomierten Kaninchen nahm durch die täglich 
einmal 5 sowie 10 'Tage lang durchgeführte Injektion des Prolans die durch Indolinjektion verursachte Indicanausscheidung im Urin beträchtlich ab. Die Wirkung des Prolans auf die Indicansynthese im Organismus ist also auch bei ovariektomierten Kaninchen konstatierbar.

(Autoreferat)

\title{
Über die Beziehung zwischen der Indicansynthese im Organismus und der Hypophyse. III. Mitteilung. Über den Einfluss des sogenannten Hypophysenvorderlappenhormons bei männlichen Kaninchen.
}

\author{
Von \\ Dr. E. Sanada. \\ (Aus der 1. Med. Klinik der Kaiserl. Universität zu Kyoto in Japan. \\ Direktor: Prof. Dr. K. Tsuji)
}

In dieser Mitteilung untersuchte der Verfasser die Veränderung der Indicansynthese bei der Indolinjektion am erwachsenen männlichen sowie am splenektomierten Kaninchen, woza es durch wiederholte Injektion des sogenannten Hypophysenvorderlappenhormons, d. h. des Prolans, kommt.

Die Ergebnisse waren die folgenden:

1) Bei erwachsenen männlichen Kaninchen nahm durch die täglich einmal 5 Tage lang durchgeführte Injektion des Prolans die durch Indolinjektion verursachte Indicanausscheidung im Urin deutlich ab. Die täglich einmal 10 Tage lang dnrchgeführte Injektion des Prolans führte auch zu einer Abnahme der Indicansynthese.

2) Bei erwachsenen männlichen Kaninchen mit exstirpierter Milz kam es durch wiederholte Injektion des Prolans zu der obenberichteten Wirkung nicht. Das bedeutet, dass die wirkasame Substanz, die das Prolän enthält, auf dem Wege über die Milz wirken dürfte.

(Autoreferat) 